\title{
How University Entrepreneurship Support Affects College Students' Entrepreneurial Intentions: An Empirical Analysis from China
}

\author{
Genshu Lu ${ }^{1}\left(\mathbb{D}\right.$, Yaping Song ${ }^{2, *}$ and Bingchao Pan $^{2,3}$ \\ 1 Department of Sociolgy, School of Humanities and Social Science \& West China Higher Education Evaluation \\ Centre, Xi'an Jiaotong University, Xi'an 710049, China; gslu@mail.xjtu.edu.cn \\ 2 School of Public Policy and Administration, Xi'an Jiaotong University, Xi'an 710049, China; \\ bchpan@stu.xjtu.edu.cn \\ 3 School of Educational Science, Shaanxi Xueqian Normal University, Xi'an 710100, China \\ * Correspondence: songyaping@stu.xjtu.edu.cn
}

check for updates

Citation: Lu, G.; Song, Y.; Pan, B. How University Entrepreneurship Support Affects College Students' Entrepreneurial Intentions: An Empirical Analysis from China. Sustainability 2021, 13, 3224.

https://doi.org/10.3390/su13063224

Academic Editor: Christian Rammel

Received: 7 February 2021

Accepted: 9 March 2021

Published: 15 March 2021

Publisher's Note: MDPI stays neutral with regard to jurisdictional claims in published maps and institutional affiliations.

Copyright: (c) 2021 by the authors. Licensee MDPI, Basel, Switzerland. This article is an open access article distributed under the terms and conditions of the Creative Commons Attribution (CC BY) license (https:/ / creativecommons.org/licenses/by/ $4.0 /)$.

\begin{abstract}
Given the major role of new enterprises founded by university alumni in creating employment and promoting economic development, it is well known that Chinese universities have implemented plenty of impressive initiatives to support students' entrepreneurship. However, little is yet known about how students evaluate university entrepreneurship support and how it affects students' entrepreneurial intentions. This study utilizes 13,954 recent college graduates from Chinese higher education institutions as a sample and aims to examine students' perceptions of the support they received from universities and its influence on students' entrepreneurial intentions. The results illustrate that students are not very satisfied with various university entrepreneurship supports. Findings also indicate that university entrepreneurship support positively impacts students' entrepreneurial intentions, although it is not a very strong relationship. Moreover, university entrepreneurship support positively affects entrepreneurial attitude, subjective norms, and entrepreneurial self-efficacy, which in turn determine entrepreneurial intention. Entrepreneurial attitude, subjective norms, and entrepreneurial self-efficacy play a mediating role between university entrepreneurship support and entrepreneurial intention. The study contributes to the entrepreneurial literature theoretically and provides practical recommendations for policymakers and university administrators in China to reconsider and improve their entrepreneurship supports to encourage more students to become entrepreneurs.
\end{abstract}

Keywords: university entrepreneurship support; entrepreneurial intention; entrepreneurial attitude; social norms; entrepreneurial self-efficacy; influence mechanism

\section{Introduction}

Entrepreneurship is an essential engine of job creation, innovation, and sustainable economic development in all countries. In parallel college students are considered as the most promising source of entrepreneurs [1]. Therefore, governments across the globe take entrepreneurship as a priority and build an entrepreneurial ecosystem starting from policy supply, financial support, entrepreneurship education, and atmosphere creation to encourage college students to start a venture. However, the number of college graduates starting ventures has not grown significantly [2], especially in developing countries like China. According to the "Report on Employment of Chinese College Students in 2019" released by Mycos, college graduates' entrepreneurial rate in 2018 was only 2.7\% [3], which still has a significant gap compared to European and American university graduates. Consequently, it is necessary to further research the various factors that affect college graduates' entrepreneurship, especially in a Chinese context.

Previous research has proven that entrepreneurial intention is the best predictor of entrepreneurial behavior [4]. Therefore, entrepreneurial intention and its influencing 
factors have been increasingly attracting more attention from researchers. In prior studies, individual characteristics, e.g., gender [5], personality and traits [6], entrepreneurial mindset [7]; family background factors (e.g., prior family business exposure [8], parents' employment status and occupational status) [9]; social-environmental factors (e.g., the regional policy) [10] have been extensively discussed. However, the university factors for students' entrepreneurial intentions mainly focus on the analysis of entrepreneurship education [11-13], and the role of other aspects of university support has not attracted enough attention. To better understand the role of universities, as Kraaijenbrink et al. [14] argued, it is necessary to evaluate the present condition of university supports from a comprehensive perspective and their impact on students.

Despite several researchers studying the role of university support and environment informing college students' entrepreneurial intentions, many issues remain. First, a few studies have examined the direct influence of university support on entrepreneurial intentions, yet, their research results have not been consistent. For example, a survey study [15] discovered no significant relationship between entrepreneurship support programs and self-employment intentions. Another survey [16] also found that perceived university support is not significantly associated with the crucial antecedents of entrepreneurial intentions (i.e., perceived desirability and feasibility). In contrast, other researchers found a positive connection between them [14,17-19]. The ambiguous results on the relationship between university support and entrepreneurial intentions indicate that researchers need to conduct more research to examine their relationship. Furthermore, as an influencing mechanism, the mediating role of self-efficacy has been verified [20]. Still, there is a dearth of research on the mediating effects of entrepreneurial attitude and subjective norms.

More importantly, in the Chinese context, it is a remarkable fact that in the past two decades, the government has focused on the crucial role of higher education institutions in stimulating individual entrepreneurship and building an entrepreneurial society, and has formulated and promulgated various policies (e.g., [21,22]), and calls on universities to provide the necessary support for college students' entrepreneurship. With government promotion, Chinese universities have made lots of efforts in entrepreneurship courses, lectures, competitions, training programs, practical conditions, financial support, etc., to inspire college students' entrepreneurship. Specifically, by the end of 2017, various universities had built 2080 innovation and entrepreneurship education institutions, held 33,994 relevant lectures, had 22,787 professional teachers, and 105,985 entrepreneurship mentors [23]. Additionally, as of the end of 2018, the total number of innovation and entrepreneurship education and practice platforms has reached 8253 (7.50 on average), and 45,712 entrepreneurial practice bases (56.43 on average); statistics also show that in 2018, Chinese universities opened a total of 27,283 innovation and entrepreneurship courses (25.24 on average) [24]. Nevertheless, it is not clear what college graduates think of these supports and how they affect students' entrepreneurial intentions.

To test the role of university supports from a comprehensive perspective, further clarify the relationship between university support and college students' entrepreneurial intentions, and help universities improve their internal entrepreneurial ecosystem, we are going to use the theory of planned behavior (TPB) as the basic framework to explore four research questions:

1. How do students evaluate the entrepreneurship support provided by universities?

2. Does perceive university entrepreneurship support have a direct impact on college students' entrepreneurial intentions;

3. Does perceive university entrepreneurship support indirectly affect college students' entrepreneurial intentions through entrepreneurial attitude, subjective norms, and selfefficacy;

4. How can universities be more efficient in providing students with entrepreneurial support?

The contributions of this study are manifold. First, we use large-scale survey data from China to examine the direct and indirect effects of university support on college 
students' entrepreneurial intentions, which will increase people's understanding of the role universities play in shaping college students' entrepreneurial intentions in China. To our knowledge, several previous studies were conducted in Pakistan [25], India, Malaysia, Singapore [26], Indonesia [27], and other countries; but no one has systematically studied the impact of university entrepreneurship support on college students' entrepreneurial intentions in the Chinese context. Second, our research findings may help add new evidence to the controversies of previous studies on the relationship between university support and college students' entrepreneurial intentions. Third, although researchers have tested the direct effect of university environment and support on students' entrepreneurial attitude and entrepreneurial intentions, as well as the mediating effect of self-efficacy. Nevertheless, the influence of the university environment on subjective norms and the mediating role of entrepreneurial attitude and subjective norms are still unknown. The results of this study could make up for the deficiencies of existing studies. Fourth, the study has important implications for practice: findings may be used to help policymakers and universities understand the effectiveness of current practices and initiatives and help them design more effective entrepreneurial support policies and programs.

In what follows we first review the theoretical foundation for the study and literature on entrepreneurial intentions and university support, and propose a series of hypotheses. After that, we provide research methodology. Followed by an explanation of the study results. Last, we discuss the results, and their implications are provided along with limitations and future direction.

\section{Theory and Hypotheses}

\subsection{Theoretical Background}

Research on entrepreneurship in western developed countries has a long history. From the 1960s to the 1970s, researchers focused on how entrepreneurs' personality traits distinguish entrepreneurs from non-entrepreneurs. Some researchers, for example, asserted that compared with people who have not started a business, entrepreneurs often show some personality characteristics, including achievement motivation, self-confidence, etc. $[28,29]$. However, it is disappointing that entrepreneurs' personality traits cannot effectively explain their entrepreneurial decisions [30] since, in the real environment, individuals with similar characteristics may take different behaviors. Similarly, people with different characteristics may have the same response [31]. Since the 1980s, researchers have gradually turned their research focus to cognitive variables, precisely entrepreneurial intentions, and identified several entrepreneurial intention models worthy of further investigation; these models provide new ways to predict and understand entrepreneurship. After entering the 21st century, researchers have introduced several new models based on revising or criticizing the early entrepreneurial intention models. For example, Carsrud and Brännback [32] pointed out that previous entrepreneurial intention models were often linear and static. To avoid this limitation, they developed the Contextual Model of Entrepreneurial intentions.

Among the existing entrepreneurial intention models, the entrepreneurial event model (EEM) [33] and the theory of planned behavior (TPB) [34] have received widespread discussion. EEM is the first entrepreneurial intention model based on cognitive theory. Depending on EEM, entrepreneurial behavior choice depends on three factors, perceived desirability, perceived feasibility, and propensity to act. Perceived desirability refers to the attractiveness of entrepreneurial behavior that an individual can perceive; perceived feasibility is defined as the degree to which an individual feels that they can carry out entrepreneurial behavior, and propensity to act is the likelihood to start a business. It is worth noting that in EEM, besides these three variables, the trigger events are also crucial for individual entrepreneurship. The trigger events, which can often be harmful (e.g., job loss or divorce) but can also be positive (e.g., inheriting an estate or winning the lottery), forcing the decision-makers to select the best opportunity from a series of choices. The TPB, advanced by Ajzen [34], assumes that much human behavior is under voluntary control 
and planning; behavioral intention exists before the action. At the same time, the intention is influenced by three main antecedents: attitude toward behavior (ATB), subjective norms (SN), and perceived behavior control (PBC). Among them, ATB refers to the individual's positive or negative evaluation of the behavior, SN is the social pressures perceived by the individual to perform or not to perform a particular behavior, and PBC means people's perception of how difficult it is to serve the target behavior [34].

As two conceptual models broadly accepted and used in the entrepreneurship research domain, EEM and TPB have likenesses and differences. On the one hand, both models overlap in two aspects: first, in general, other influences operate through person-situation perceptions that the three factors (ATB, SN, and PBC) in TPB and two factors (desirability and feasibility) in EEM, do not affect intentions or behavior independently [28]. Further, perceived desirability in the EEM is equivalent to ATB and SN in TPB, whereas perceived feasibility is like PBC in TPB [35]. On the other hand, both models are not identical. One principal difference is that EEM assumes that inertia guides human behavior until something interrupts or displaces that inertia. In other words, EEM is based on triggering events, while the TPB model does not have this consideration.

EEM and TPB have been rigorously tested and validated in the literature [36]. The following two points we have taken into consideration when deciding which theory is most applicable to this research: first, the purpose of our study is to explore how university entrepreneurship support affects college students' entrepreneurial intentions, which does not involve the impact of trigger events. Second, from the model's explanatory power, a meta-analysis by Schlaegel and Koenig [37] found the TPB explains much variance in entrepreneurial intention than EEM (EEM: $R^{2}=0.21$; TPB: $\left.R^{2}=0.28\right)$. So, the present study chooses TPB as the primary analytical framework.

However, it should be noted that when applying the TPB to analyze individual entrepreneurial intentions, the researchers' selection of the three antecedent variables of intention shows a rather heterogeneous picture. Regarding the first component, scholars suggest that attitude is a crucial predictor of behavioral intention, so they generally tend to keep it in the study. As far as the SN of the second component, some studies found that it is the weakest predictor of intentions [38]. As a result, some authors have directly omitted it from their analysis $[39,40]$. However, we intend to keep this variable in our research because it is considered that $\mathrm{SN}$ could be different across cultures and more supportive in some countries than in others [41]. In other words, the influence of SN depends on the cultural context. Notwithstanding, the results are still mixed in collectivistic cultures, which shows that it is necessary to further test the importance of SN [42]. For the last structure, although evidence from the meta-analysis suggested that PBC is a useful variable for predicting behaviors and behavioral intentions [43], due to the likeness between PBC and self-efficacy (S-E), the conceptual and methodological methods of PBC have become quite ambiguous. Conceptually, PBC is defined as the individual's perception of the extent of ease or difficulty of performing the target behavior [34]. Perceived S-E refers to the people's beliefs in their capabilities to complete specific tasks [44]. Obviously, both PBC and S-E are cognitive and control-based, and there is a considerable degree of overlap between them so that some people think their structures are interchangeable [34]. In empirical research, the meta-analysis of PBC indicated that a few studies only use items related to controllability, but most employ either S-E items alone or combined S-E and controllability items [45]. When considering whether to use S-E or PBC, we focus on their interpretation powers. Studies have found that the S-E measure makes substantial and significant contributions to intentions, whereas PBC has no effect or little effect on intentions [46-48]. Accordingly, in this paper, even though we are using TPB, we advocate adopting S-E instead of PBC in predicting entrepreneurial intentions [49] and focusing on explaining S-E's effect on intention. 


\subsection{University Entrepreneurship Support and Entrepreneurial Intention}

\subsubsection{University Entrepreneurship Support}

Behavior does not exist in a vacuum [50]. Entrepreneurship is a complex social activity that involves discovering, evaluating, and exploiting opportunities. These activities need extensive and diverse resources, which are in the hands of the government, organizations, and individuals. Among them, universities are increasingly regarded as critical institutions for developing national entrepreneurship through teaching, research, and outreach [51]. According to universities' organizational characteristics, university entrepreneurship support (UES) is mainly based on entrepreneurial education support while considering other support aspects. In this sense, the UES we refer to is a concept broader than entrepreneurial education, which includes a portfolio of entrepreneurial support activities. Based on descriptions of university's entrepreneurship support factors in the literature (e.g., [52]) and a search of current practical experience in major universities in China, we suggest that UES should be grouped under five dimensions: entrepreneurial education, entrepreneurial climate, entrepreneurship management measures, entrepreneurial practical training conditions, and entrepreneurship services programs.

\subsubsection{Entrepreneurial Intention}

Entrepreneurial intention (EI) is derived from "intention" which is an essential concept of psychology. In fact, there are multiple definitions of intention available in the literature. For instance, in Bird's opinion, the intention is a state of mind that leads an individual's attention, experience, and action to a specific goal or path to achieve the goal [53]. Ajzen defines intention as the degree to which people show the motivation to perform desired behaviors [34]. Bandura holds that intention is not simply anticipation or expectation of future action but a proactive commitment to act [54].

As conceptual as the diversity of intentional concepts, researchers have expressed their opinions on the definition of an individual's EI. Some researchers equate initial entrepreneurial actions taken by individuals before officially starting a business, including writing a business plan, searching for information, and looking for a building or equipment $[55,56]$. From psychology's perspective, several researchers define EI as the attitude that potential entrepreneurs have towards whether to start entrepreneurial activities [35]; it is a mental state of entrepreneurs aiming to create a new business or add value to an existing organization [57]. Besides, from the perspective of probability, some scholars regard it as the possibility of individuals starting a business in the future [58]. As described above, EI is a pre-factor in the entrepreneurial process that may lead individuals to create and manage new enterprises. In line with prior research [59], we define EI as the psychological tendency of individuals to choose entrepreneurship in the future.

\subsubsection{The Relationship between University Entrepreneurship Support and Entrepreneurial Intention}

The essential feature of UES is the entrepreneurial environment created by the university. Theoretically, first, according to Krueger and Brazeal's "Entrepreneurial Potential Model" [35], the university can create a "nutrient-rich" environment that can provide reliable information and role models, emotional/psychological support, and more material resources to stimulate entrepreneurial behavior. Second, from the theory of human capital and social capital, the basic principles of the relationship between UES and EI depend on the importance of resources like knowledge, skills, relation, and materials in establishing and operating enterprises. A university's entrepreneurial education support such as entrepreneurship courses, training, and lectures can help college students obtain entrepreneurial information and accumulate entrepreneurial knowledge, skills, and additional capacities. It can also allow students to contact influential personnel, including entrepreneurial investors, suppliers, distributors, potential customers, partners, and like-minded students. These social networks facilitate college students obtaining the necessary entrepreneurial social capital, especially for college students who lack family 
support. Third, Granovette's embedded theory suggests that individual behavior will be guided or restricted by the surrounding environment [60]. An excellent entrepreneurial climate means that in universities, entrepreneurship is considered a reliable and respectable career choice. There is no doubt that this collective cognition is beneficial to emotionally and psychologically reducing college students' aversion to entrepreneurial risks and entrepreneurial failure. Finally, according to the entrepreneurial event model, services such as university entrepreneurship policies, training conditions, and funds may enhance the college students' perceived feasibility of entrepreneurship and become a trigger to stimulate their entrepreneurial intentions.

In empirical research, it is widely suggested that university entrepreneurship education, climate, policies, funds, and other support positively affect entrepreneurial intentions. For example, Lüthje and Franke [17] conducted an analysis using a sample of 512 students at MIT and revealed that the university's entrepreneurial climate does make a direct contribution to students' EI. In another empirical study, they found that the imperfect and immature entrepreneurship education and various university support conditions may dampen students' optimism for entrepreneurship [61]. Nasiru et al. [62] advanced that perceived university support raises students' entrepreneurial intentions. Likewise, a recent study found a similar finding that the entrepreneurial university environment directly and significantly affects entrepreneurial intentions [63]. As such, it is reasonable to expect that UES may enhance college students' entrepreneurial intentions. Taken together, we propose:

Hypothesis 1 (H1). University entrepreneurship support positively affects students' entrepreneurial intention.

\subsection{University Entrepreneurship Support and Entrepreneurial Attitude, Subjective Norms, and Entrepreneurial Self-Efficacy}

Entrepreneurial attitude (EA) reflects an individual's views, opinions, and preferences for entrepreneurship [58]. According to the TPB, EA is affected by the expected results and the outcomes' impact in multiple aspects [34]. The positive anticipated results such as higher economic returns, independence, or autonomy may make people have a positive attitude towards entrepreneurial behavior; on the contrary, negative expectations of behavior results will discourage entrepreneurial enthusiasm [64]. Studies have shown that attitude is affected by personality, education, personal values, prior experience, etc. [65]. As such, it has been argued that entrepreneurship education can foster positive EA among college students by emphasizing entrepreneurship benefits [66]. Besides, universities' entrepreneurial training opportunities and financial support may reduce students' aversion to entrepreneurial risks and promote a positive EA.

Subjective norms measure the perceived social pressure that important "reference people" would expect or not expect us to start a business [67]. This pressure can come from "important others" such as parents, friends, and partners, or from the groups and society where the individual belongs. Ajzen and Fishbein argued that SN are determined by normative beliefs and motivation to comply [68]. Normative beliefs are the perceived expected beliefs of salient individuals or groups perceived on whether they should perform a specific behavior; motives to comply with an individual's intention to obey others' expectations. Generally, students are more likely to launch new ventures when they perceive that their university's environment supports them [25]. This may be because the UES demonstrates the expectations of the government, universities, and society for college students' entrepreneurship and provides the possibility for them to follow the expectation and start entrepreneurial activities.

Self-efficacy refers to an individual's perception of the ability to perform a target behavior [69]. According to Bandura's self-efficacy theory, self-efficacy beliefs come from four sources: previous attainments or mastery experience, vicarious experience of observing others, verbal and social persuasions, and emotional and physiological conditions [70,71]. Mastery experience is obtained from personal experience, and vicarious experience is 
the cognition obtained by observing the behavior and preference of others, while verbal persuasion is a means of securing ability and belief through the encouragement, praise, and suggestion of others; the physiological and affective states such as strength versus strain, relaxation versus stress can affect an individual's judgment of their abilities. With respect to entrepreneurial self-efficacy (ESE), university entrepreneurship education can enhance students' belief in coping with entrepreneurial challenges through the imparting of entrepreneurial knowledge and the enhancement of entrepreneurial capabilities; university entrepreneurship practical training conditions such as entrepreneurial centers and incubators can provide them with access opportunities for enactive mastery experience; as a common method for universities to create the entrepreneurial climate, publicizing alumni's successful business stories allows students to gain vicarious experience through comparison with social models; similarly, encouragement and praise from teachers, classmates, and alumni can serve as kinds of social persuasion to promote students' ESE. Apart from the above theoretical analysis, empirical research also shows that UES is positively correlated with ESE. For instance, Saeed et al. [25] reported that perceived educational support, concept development support, and business development support significantly impact college students' ESE. Similarly, Trivedi [26] also found that university support that is targeted cognitive and non-cognitive support, general educational support positively affects ESE.

In all, various UES are expected to offer knowledge, skills, confidence, and resources needed for entrepreneurship to students to boost their EA, SN, and ESE. So, we hypothesize that:

Hypothesis 2 (H2). University entrepreneurship support positively affects students' entrepreneurial attitude.

Hypothesis 3 (H3). University entrepreneurship support positively affects students' subjective norms.

Hypothesis 4 (H4). University entrepreneurship support positively affects students' entrepreneurial self-efficacy.

\subsection{Entrepreneurial Attitude, Subjective Norms, Entrepreneurial Self-Efficacy, and Entrepreneurial Intention}

According to TPB, behavioral intention is given in three antecedent variables: EA, SN, and PBC (ESE). The more positive the attitude towards entrepreneurship and the more support from the reference group, the higher the ESE and the greater the individual EI.

EA usually includes two dimensions: an emotional component (pleasure) and a cognitive component (attractive, advantageous). From the rational choice theory, individuals pursue the maximization of their interests as reasonable people; this means entrepreneurial decisions may come from personal career choices that maximize utility. People will decide to start a business if they predict that entrepreneurial activities' total utility (e.g., affective or advantages) will be greater than other career choices. Likewise, relevant empirical studies also suggested that EA plays an influential role in individual EI. For instance, the research of Maresch et al. [72] found the EA and EI of Austrian college students are positively correlated, and the correlation coefficient between them is 0.517 . The survey of 401 students from Vietnam National University (VNU) by Khuong and An [31] found that positive and negative perception toward entrepreneurship has significant positive and negative effects on college students' entrepreneurial intentions, respectively. Additionally, a study conducted by Mahfud et al. of 215 polytechnic students in Indonesia suggested that entrepreneurship attitude directly affects startup intention [73].

Along with EA, individual EI is also impacted by SN. As mentioned earlier, subjective norm represents the individual's perceived social-environmental pressure. For college students, normative pressure can come from society, university, family, and peers, especially those important to them. However, complying or not complying with these norms 
is related to the strength of the internal locus of control. In general, these norms' impact and predictive power tend to be weaker for individuals with a high internal locus of control [74]. In the previous empirical literature, although some studies have not found a significant positive relationship between SN and EI [75], studies also showed that it positively affected EI. For instance, the analysis of 117 working-age individuals in western Finland by Kautonen et al. [76] showed that subjective norm positively affects the sample's entrepreneurial propensity. In a separate study, Kautonen et al.'s longitudinal survey of 969 adults in Finland and Austria found that subjective norm has the strongest predictive effect on EI [77].

For ESE, its effects on EI may be based on the following reasons. First, individuals with a high level of self-efficacy are more likely to act or persevere when encountering difficulties [78]. Second, they like challenges and have a high need for achievement [79]. Third, they increase effort in the face of failure and owe failure to lack of effort instead of lack of ability [80]. Lastly, they are more optimistic in forecasting the result of behavior [81]. In all, drawing from entrepreneurship literature, ESE has been a pivotal factor influencing entrepreneurial intentions. For example, Bullough et al. [82] using survey data from Afghanistan, found that self-efficacy positively affects people's entrepreneurial intentions. Likewise, an empirical study by Asimakopoulos et al. [83] also found that ESE has a positive influence on EI.

Following the above discussion, this study proposes hypotheses:

Hypothesis 5 (H5). Entrepreneurial attitude positively affects students' entrepreneurial intention.

Hypothesis 6 (H6). Subjective norms positively affect students' entrepreneurial intention.

Hypothesis 7 (H7). Entrepreneurial self-efficacy positively affects students' entrepreneurial intention.

\subsection{The Mediating Role of Entrepreneurial Attitude, Subjective Norms, and Entrepreneurial Self-Efficacy}

The cognitive theory provides an opportunity for researchers to explore entrepreneurial decision-making and the entrepreneurial process by establishing the relationship between the entrepreneur's cognitive behavior, entrepreneurial environment, and entrepreneurial behavior [84]. As discussed before, according to TPB, entrepreneurial intentions have three decisive motivational factors or antecedents: EA, SN, and PBC (ESE). In turn, other distal factors such as traits and demographics are expected to indirectly affect EI through the three motivational structures [85]. In this sense, UES as a distal construct may indirectly affect entrepreneurial intentions through EA, SN, and ESE.

More specifically, first, TPB assumes that the more positive an individual's attitude towards a particular behavior, the stronger the intentions to perform it. Given that attitude is not as stable as personality traits, it can be changed with time and the interaction between the individual and environment [86]. Thus, in the process of studying, college students' EA may be influenced by the strong university entrepreneurial climates, various entrepreneurial education activities (e.g., courses, lectures, and competitions), supportive entrepreneurial management measures, entrepreneurship practical training conditions (e.g., pioneer park), and entrepreneurship services programs (e.g., venture capital support). Second, SN express the individuals' perceptions of external pressure. The TPB holds that individuals intend to act a certain behavior when they perceive great approval from others. When students choose entrepreneurship as a career option, it does not take place in isolation. Conversely, their decisions are often made after consultation with important people in their social networks, with people who are trusted advisors (e.g., family members, friends, teachers, etc.) [87]. Therefore, the attitudes and expectations of university teachers, classmates, friends, etc., toward student entrepreneurship may impact their decision to choose self-employment. Third, according to Bandura [69], confidence in 
successfully performing a behavior or self-efficacy is instrumental in determining whether an individual will participate in a certain behavior. An individual may intend to startup when he/she has a strong belief in their skills and abilities. The knowledge of opportunity recognition, market analysis, business planning, and managing a new venture provided by university entrepreneurship education can enhance students' confidence and make them feel more competent to complete entrepreneurial tasks [88]. University entrepreneurship training conditions can help students obtain direct entrepreneurial experience through simulation exercises. Inviting prestigious entrepreneurs, especially alumni entrepreneurs, to give lectures can allow them to gain vicarious experience. Verbal/social persuasion or encouragement from teachers and classmates also help promote students' ESE.

Based on the above discussion, it might be expected that UES will significantly influence students' EA, SN, and ESE, which in turn enhance their EI. Accordingly, we formulate hypotheses:

Hypothesis 8 (H8). Entrepreneurial attitude mediates the relationship between university entrepreneurship support and students' entrepreneurial intention.

Hypothesis 9 (H9). Subjective norms mediate the relationship between university entrepreneurship support and students' entrepreneurial intention.

Hypothesis 10 (H10). Entrepreneurial self-efficacy mediates the relationship between university entrepreneurship support and students' entrepreneurial intention.

In summary, we postulate a model where UES may directly influence EI or indirectly affect EI through EA, SN, and ESE. Figure 1 shows our research model.

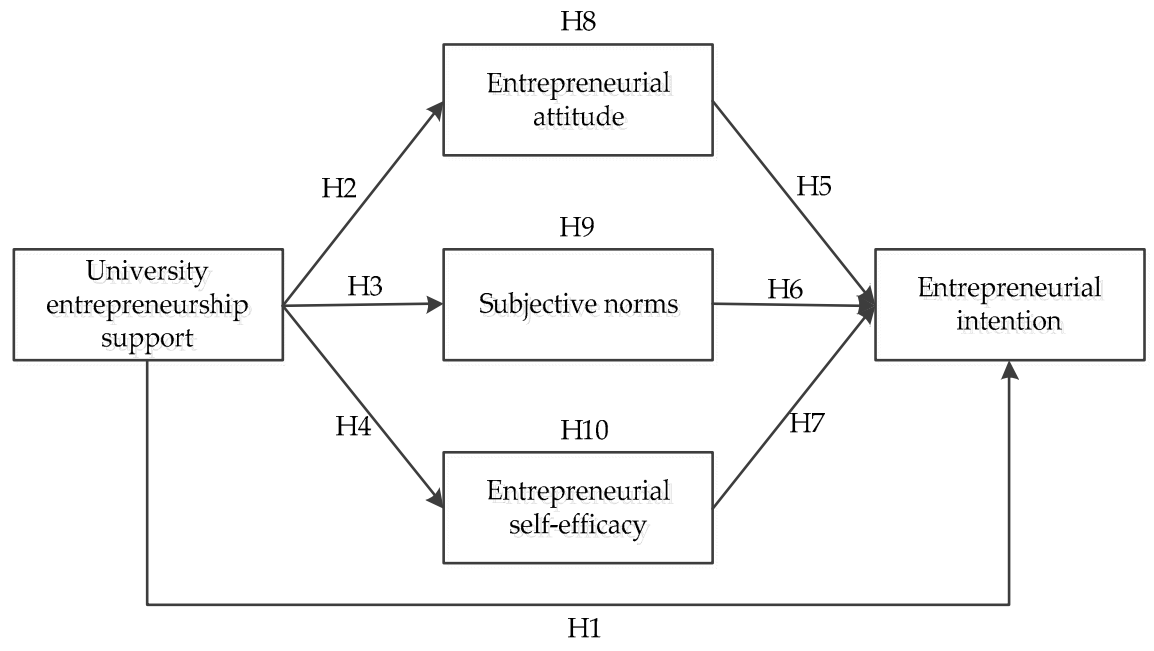

Figure 1. The conceptual model.

\section{Methodology}

\subsection{Data Collection and Sample Characteristics}

Data used to test our hypotheses were part of a large graduate annual survey project in China, which was carried out by the West China Higher Education Evaluation Center of $\mathrm{Xi}^{\prime}$ an Jiaotong University. Since 2016, four consecutive surveys have been conducted to investigate students' learning experience, employment, and entrepreneurship who graduated from universities in Shaanxi Province of China. From November 2018 to April 2019, we sent out survey invitations to all graduates via email and provided a link to our online questionnaire. We ensured respondents that their responses would not be leaked and would only be used for academic purposes. In the end, more than 40,000 students responded and 
filled out the questionnaire. After excluding the incomplete answers, 13,954 questionnaires suitable for this study were retained.

Of the 13,954 convincing respondents, $51.0 \%$ were male, $18.3 \%$ and $57.22 \%$ came from double-first-class and non-double-first-class universities, respectively, $24.13 \%$ from vocational and specialized higher education institutions, $69.6 \%$ had a bachelor's degree, and the rest had an associate degree. Table 1 presents the respondent profile.

Table 1. Participant profiles $(\mathrm{N}=13,954)$.

\begin{tabular}{ccc}
\hline Respondents' Characteristics & Absolute Frequencies (N) & Absolute Frequencies (\%) \\
\hline Gender & & 51.0 \\
Male & 7116 & 49.0 \\
Female & 6838 & 18.3 \\
Institution & 2557 & 57.22 \\
Double-first-class university & 7984 & 24.13 \\
Non-double-first-class university & 3367 & 0.3 \\
Vocational and specialized higher & 46 & 69.6 \\
education institutions & & 30.4
\end{tabular}

\subsection{Measures}

\subsubsection{Dependent Variables}

When measuring entrepreneurial intentions, previous studies mainly used two methods: categorical measures and continuous measures. Categorical measures, for example, include Lee and Wang [89], who adopted the respondents' answers to the question "whether the individual has the intention to start a business" to judge their entrepreneurial intentions. Continuous measures include, for instance, Gelderen et al. [66], who used five items such as "I have considered running a company by myself" to measure individual entrepreneurial intentions. In comparison, categorical measures are often too simple to reflect the differences between personal EI [90], and its reliability and validity are usually unsatisfactory. In contrast, continuous measures can overcome the shortcomings of categorical measures.

Hence, in this study, we follow Ajzen's [34] definition of intention and his recommendations for measurement, and based on the measurement instruments of previous researchers [91,92], employed continuous measures method to measure students' entrepreneurial intentions from six dimensions consisting of career preference, behavioral expectancies, interest, preparation, desires, and restricted entrepreneurship options. These questions such as: "My career goal is to be an entrepreneur, and I will make all effort to startup" (EI1), "I want to start and run my own company shortly or in the next 3 to 5 years" (EI2), "I am interested in things related to entrepreneurship" (EI3), "I often search for information about entrepreneurial opportunities" (EI4), "Even if fail, I will persist in starting a business" (EI5) and "Even if my parents object, I will devote myself to my own business" (EI6). A 5-point Likert scale was used to measure the above six questions, with scores ranging from strongly disagree (" 1 ") to strongly agree (" 5 ").

\subsubsection{Independent Variables}

This research conceptualizes UES as a variety of supports provided by the university for students to start their businesses. Conceptually, UES should include different support dimensions. These dimensions have different theoretical meanings and have no common theme. In other words, UES can be characterized by various combinations of its dimensions, and a university's entrepreneurship support can mainly focus on certain aspects (such as entrepreneurship education), or it can attach importance to all aspects at 
the same time. Each one of the dimensions explains a part of the latent concept. Therefore, it may be more appropriate to measure with a formative construct. Moreover, to be realistic, considering that graduate entrepreneurship is only part of our research, but not all, formative measures also have the advantages of simplifying surveys and saving respondents time.

To ensure that the selected indicators as a whole capture the entire domain of UES, the researchers first determined the scope of the construct via a literature review and then form an expert panel to further discuss, evaluate, and establish the content validity of UES [93]. Finally, we specified five items to assess UES. The respondents were asked to assess the university's efforts to support student entrepreneurship based on actual conditions: "university entrepreneurship education" (UES1), "university's entrepreneurial climate" (UES2), "university management measures to support student entrepreneurship" (UES3), "entrepreneurship practical training conditions provided by the university (e.g., pioneer park, Hackerspace, start-career training camp)" (UES4) and "entrepreneurship services provided by the university (e.g., venture capital support, help contact entrepreneurial mentors and settle in the technology park)" (UES5). Each item was measured on a 5-Likert scale ranging from very bad ("1") to very good ("5").

\subsubsection{Mediating Variables}

Depending on our research hypotheses, the EA, SN, and ESE may mediate the relationship between UES and college students' EI. Therefore, we enquired about the respondents' EA, SN, and ESE. All scale items were measured using a 5-point Likert scale from strongly disagree ("1") to strongly agree (“5”).

Entrepreneurial attitude: To measure the attitude towards entrepreneurship, we employed a scale consisting of five items adapted from Liñán and Chen's [91] study: "Being an entrepreneur appeals to me a lot" (EA1), "I am more interested in starting my own business than looking for a job" (EA2), "Entrepreneurship has more advantages than disadvantages for me" (EA3), "I would like to startup if I have the opportunity and resources," (EA4), and "I am willing to pay the price for entrepreneurship" (EA5).

Subjective norms: SN should be measured using "what do reference people think?" [34]. In our study, it was constructed using four items adapted from Liñán [94] to measure the perceptions of parents, immediate family members, classmates, and friends on whether an individual should startup or not. The specific questions are as follows: "My parents and immediate family members believe that starting a business is more valuable than finding a job" (SN1), "My parents and immediate family members support me to start a new firm" (SN2), "My classmates and friends argue that starting a business is more valuable than finding a job" (SN3), and "My classmates and friends support me to start a business" (SN4).

Entrepreneurial self-efficacy: we used the following five items to capture the ESE level of college students based on the work of Liñan and Chen [91]: "I believe it is easier for me to start a business" (ESE1), "I believe I can choose a promising industry to start a business" (ESE2), "I believe that my knowledge, ability, and quality will help me succeed in starting a business" (ESE3), "I believe that my own life and work experience will help me successfully start a business" (ESE4), and "If I start a business, I have a great chance of success" (ESE5).

\subsection{Methods for Data Analysis}

Descriptive statistics, partial least squares structural equation modeling (PLS-SEM) were utilized to conduct the data analysis. First, in response to the first research question, a descriptive statistical method was used to analyze college graduates' evaluation for UES. Next, the PLS-SEM approach instead of the traditional covariance-based structural equation model (CB-SEM) technique was used to test the structural relationships. As a multivariate statistical method generally used in various fields, CB-SEM has strong statistical power and available structural model overall goodness of fit criteria. However, it needs to identify the model before it can converge to the allowable results [95]. Specifically, 
when the model contains formative constructs, the identification of formative structure requires a necessary condition: the variable must emit at least two paths to other (reflective) constructs [96]. This identification rule might seem available; however, the problem is the reflective constructs used for identification will affect the loading of the relationship between formative indicators and formative latent variables, which in turn affects the meaning of construct itself. Thus, this approach makes researchers doubt the independence of the formative latent variables' concept [97] and leads to interpretational confounding. In contrast, prior studies have argued that PLS-SEM has fewer identification issues as well as being easy to use with formative measurement models [98]. Moreover, it yields more accurate estimates of the interaction effects by considering additional incremental measurement errors [99].

The analysis of PLS-SEM occurs in two steps. The first step is to evaluate the reliability and validity of measurement depending on the formative and reflective models' respective criteria. Specifically, for the reflective structures (EA, SN, ESE, and EI), we assessed construct' reliabilities, convergent validity, and discriminant validity. In the case of formative structure (UES), we examined the indicator's contribution to its formative construct, multicollinearity between items, discriminant validity, and nomological validity. The second step involves examining the structural model and focuses on the goodness of fit, the model's explanatory power, the capability to predict, level and significance of the path coefficients, and the robustness test of measurement results.

\section{Results}

\subsection{Descriptive Statistics}

Before analyzing each dimension of UES, we assessed their distributional properties based on the histograms, corresponding Q-Q plots, skewness, and kurtosis. Our test results reveal that the skewness and kurtosis of UES and its dimensions are within the acceptable range of normal distribution $(<|1.0|)$ [100]. Therefore, we adopted the mean and standard deviation to describe the characteristics of each dimension of UES. Table 2 presents descriptive statistics for the UES. It can be found that the respondents rate university entrepreneurship education and the entrepreneurial climate less positively than entrepreneurial management measures, entrepreneurial training conditions, and entrepreneurial services. The mean scores for the five items range between 2.95 and 3.07, with the university entrepreneurship education and entrepreneurial climate scoring the lowest and the entrepreneurial management measures scoring the highest. The results show that the UES in China remains at low levels. Although this result may disappoint university administrators and policymakers, it does provide a clue to improve their entrepreneurial support. If these universities do not change, it may limit students' entrepreneurship.

Table 2. Descriptive statistics.

\begin{tabular}{ccccc}
\hline Variable & Indicator & $\mathbf{N}$ & Mean & SD \\
\hline \multirow{2}{*}{ UES } & UES1 & 13,954 & 2.95 & 0.949 \\
& UES2 & 13,954 & 2.95 & 0.963 \\
& UES3 & 13,954 & 3.07 & 0.958 \\
& UES4 & 13,954 & 3.05 & 0.998 \\
& UES5 & 13,954 & 3.02 & 0.991 \\
\hline
\end{tabular}

Note: UES = university entrepreneurship support; UES1 = university entrepreneurship education; UES2 = university's entrepreneurial climate; UES3 = university management measures to support student entrepreneurship; UES4 = entrepreneurship practical training conditions provided by the university (e.g., pioneer park, Hackerspace, Start-career training camp); UES5 = entrepreneurship services offered by the university (e.g., venture capital support, help contact entrepreneurial mentors and settle in the technology park). 


\subsection{SEM Analysis}

\subsubsection{Measurement Model}

The SmartPLS 3.0 was employed to estimate our research model. The model includes one formative construct and four reflective constructs. Since reflective and formative structures have different evaluation criteria [101], we assessed the two types of constructs separately.

\section{Reflective Constructs}

Except for UES, the rest of the constructs (EI, EA, SN, and ESE) are reflective constructs. The adequacy of reflective constructs can be accessed via (1) individual item reliability, (2) convergent validity and discriminant validity [102,103].

The Cronbach Alpha and composite reliability were used to evaluate the reliability of measurement. Table 3 displays the reflective constructs' Cronbach Alpha scores and composite reliability (CR) values. In general, Cronbach Alpha requires a minimum of 0.7 [104]. However, for exploratory studies, values between 0.6-0.7 are considered acceptable [105]. As shown in Table 3, Cronbach Alpha values from 0.8894-0.9547 indicate high internal consistency. Besides, the $\mathrm{CR}$ values (ranging from 0.9234 to 0.9636 ) for all variables are greater than the threshold of 0.70 [106]. The above results indicate that the four reflective constructs have sufficient reliability.

Table 3. Reliability and convergent validity.

\begin{tabular}{cccc}
\hline Variable & Cronbach's Alpha & CR & AVE \\
\hline EI & 0.9547 & 0.9636 & 0.8154 \\
EA & 0.9275 & 0.9453 & 0.7760 \\
SN & 0.8894 & 0.9234 & 0.7509 \\
ESE & 0.9526 & 0.9635 & 0.8408 \\
\hline
\end{tabular}

Note: 1. EI = entrepreneurial intention; $\mathrm{EA}=$ entrepreneurial attitude; $\mathrm{SN}=$ subjective norms; $\mathrm{ESE}=\mathrm{en}$ trepreneurial self-efficacy. 2 . $\mathrm{CR}=$ composite reliability; $\mathrm{AVE}=$ average variance extracted.

In the same vein, we employed several procedures to evaluate the reflective constructs' validity. First, we evaluated convergent validity utilizing theaverage variance extracted (AVE) and factor loadings. Table 3 displays that each construct's AVE value (ranging from 0.7509 to 0.8408 ) is higher than the required threshold of 0.50 [106]. Furthermore, Table 5 shows that each item's factor loading (in bold) on their respective constructs exceeds the threshold of 0.5 and is statistically significant [107]. These results indicate all constructs have convergent validity. Second, we applied (a) the Fornell and Larcker criterion [106] and (b) the item cross-loading evaluation approach [108] to assess the discriminant validity. Table 4 states that the AVE's square root for EA is slightly smaller than the correlation between EA and EI, the AVE's square roots for EI, SN, and ESE are higher than the correlation between latent variables. This implies that the EA and EI under study may face multicollinearity and should be looked into further. Therefore, we additionally evaluated the discriminative validity of all constructs through cross-loadings. Table 5 shows that all items' loading on other constructs (cross-loadings, not bolded) are less than on their expected constructs (factor loadings, in bold). This demonstrates that reflective constructs have satisfactory discriminant validity.

\section{Formative Construct}

For the formative construct (UES), we followed the practical guidelines in existing literature $[98,109]$ to examine the indicator's contribution to its formative construct, multicollinearity between items, discriminant validity, and nomological validity.

First, to test the contribution of indicators to its formative structure, following the advice of Götz et al. [110], we examined each item's weight, sign, and magnitude to assess these item's relative importance to UES. The results (Table 6) show that the weight of UES3, UES4, and UES5 are close to zero as well as not being statistically significant, which 
indicate that these items make no significant contributions to UES, whereupon it may be feasible to considered dropping insignificant items until all weights are essential [111]. However, Diamantopoulos and Siguaw [112] also emphasized that eliminating formative structure indicators may adversely affect constructs' content validity. Therefore, to ensure that the remaining indicators still fully reflect the content of the construct's concern, the decision of dropping indicators should be combined with content analysis and other techniques [111]. Hair, Ringle, and Sarstedt [98] suggested that besides considering relative importance (i.e., the significance of the indicator's weight), the absolute importance of the indicator to its construct (i.e., the loading) should also be evaluated. When the weight and loading are not significant, there is no empirical evidence to support retaining the indicator, and its theoretical relevance should be questioned [113]. We evaluated the loading (absolute importance) and its statistical significance. The results (Table 6) show that all item's loadings range from 0.8166 to 0.9461 are statistically significant at the 0.001 level. Based on this result, given UES content integrity, we chose to keep all items even if their weights are not significant.

Table 4. Correlations and discriminant validity test.

\begin{tabular}{ccccc}
\hline Variable & $\mathbf{1}$ & $\mathbf{2}$ & $\mathbf{3}$ & $\mathbf{4}$ \\
\hline 1. EA & $\mathbf{0 . 8 8 0 9}$ & & & \\
2. EI & 0.8847 & $\mathbf{0 . 9 0 3 0}$ & & \\
3. ESE & 0.7723 & 0.7693 & $\mathbf{0 . 9 1 7 0}$ & $\mathbf{0 . 8 6 6 6}$ \\
4. SN & 0.7598 & 0.7453 & 0.7460 & 2.8200 \\
Mean & 3.0700 & 2.7900 & 2.8100 & 0.8650 \\
\hline
\end{tabular}

Note: 1. EA = entrepreneurial attitude; EI = entrepreneurial intention; ESE = entrepreneurial self-efficacy; $\mathrm{SN}=$ subjective norms. 2. Diagonal values represented in bold are square roots of AVE; off-diagonal values are the correlations between latent variable.

Table 5. The item cross-loading evaluation.

\begin{tabular}{cccccc}
\hline Variable & Indicator & EI & EA & SN & ESE \\
\hline \multirow{6}{*}{ EI } & EI1 & $\mathbf{0 . 9 0 0 8}$ & 0.7718 & 0.6584 & 0.6704 \\
& EI2 & $\mathbf{0 . 9 0 1 6}$ & 0.7563 & 0.6656 & 0.6784 \\
& EI3 & $\mathbf{0 . 8 9 4 4}$ & 0.8257 & 0.6521 & 0.6922 \\
& EI4 & $\mathbf{0 . 9 1 3 3}$ & 0.7972 & 0.6703 & 0.6962 \\
& EI5 & $\mathbf{0 . 9 2 2 1}$ & 0.8069 & 0.6905 & 0.7151 \\
EA & EI6 & $\mathbf{0 . 8 8 5 3}$ & 0.8300 & 0.6987 & 0.7127 \\
& EA1 & 0.8516 & $\mathbf{0 . 9 1 8 9}$ & 0.6833 & 0.7070 \\
& EA2 & 0.8577 & $\mathbf{0 . 9 2 0 0}$ & 0.7063 & 0.7143 \\
& EA3 & 0.8010 & $\mathbf{0 . 9 0 5 8}$ & 0.6947 & 0.6974 \\
SN & EA4 & 0.6341 & $\mathbf{0 . 8 0 6 7}$ & 0.5527 & 0.5847 \\
& EA5 & 0.7216 & $\mathbf{0 . 8 4 7 2}$ & 0.6980 & 0.6885 \\
& SN1 & 0.6099 & 0.5983 & $\mathbf{0 . 8 4 4 2}$ & 0.5934 \\
& SN2 & 0.6391 & 0.6327 & $\mathbf{0 . 8 7 3 2}$ & 0.6526 \\
& SN3 & 0.6339 & 0.6658 & $\mathbf{0 . 8 6 0 9}$ & 0.6295 \\
& ESE4 & 0.6965 & 0.7309 & $\mathbf{0 . 8 8 7 4}$ & 0.7049 \\
& ESE1 & 0.6984 & 0.6680 & 0.6806 & $\mathbf{0 . 8 8 2 9}$ \\
& ESE2 & 0.7362 & 0.7381 & 0.6997 & $\mathbf{0 . 9 2 9 9}$ \\
& ESE3 & 0.6789 & 0.7030 & 0.6622 & $\mathbf{0 . 9 2 0 6}$ \\
& ESE4 & 0.6925 & 0.7151 & 0.6711 & $\mathbf{0 . 9 2 3 6}$ \\
& ESE5 & 0.7183 & 0.7149 & 0.7044 & $\mathbf{0 . 9 2 7 1}$ \\
\hline
\end{tabular}

Note: $1 . \mathrm{EI}=$ entrepreneurial intention; $\mathrm{EA}=$ entrepreneurial attitude; $\mathrm{SN}=$ subjective norms; $\mathrm{ESE}=\mathrm{en}-$ trepreneurial self-efficacy. 2. The bold font on the diagonal line is the item loadings; the other numbers are the item cross-loadings. 3. All factor loadings are significant at the 0.001 level. 
Table 6. University entrepreneurship support (UES) indicator's weight, sign, loading, and variance inflation factor (VIF).

\begin{tabular}{ccccccc}
\hline Construct & Indicator & Weight & $\boldsymbol{p}$-Value & Loading & $\boldsymbol{p}$-Value & VIF \\
\hline \multirow{6}{*}{ UES } & UES1 & 0.3312 & $<0.001$ & 0.9461 & $<0.001$ & 5.8119 \\
& UES2 & 0.7401 & $<0.001$ & 0.9880 & $<0.001$ & 6.8732 \\
& UES3 & 0.1119 & $>0.001$ & 0.8856 & $<0.001$ & 6.2693 \\
& UES4 & -0.1050 & $>0.001$ & 0.8166 & $<0.001$ & 7.2315 \\
& UES5 & -0.0699 & $>0.001$ & 0.8289 & $<0.001$ & 7.8072 \\
\hline
\end{tabular}

Note: 1. UES = university entrepreneurship support; UES1 = university entrepreneurship education; UES2 = university's entrepreneurial climate; UES3 = university management measures to support student entrepreneurship; UES4 = entrepreneurship practical training conditions provided by the university (e.g., pioneer park, Hackerspace, Start-career training camp); UES5 = entrepreneurship services offered by the university (e.g., venture capital support, help contact entrepreneurial mentors and settle in the technology park). 2. VIF = variance inflation factor.

Second, the high multicollinearity between indicators in the formative measurement model suggests that some items may be redundant. To determine redundancy, we tested the variance inflation factors (VIF). Table 6 displays that the VIF values range from 5.8119 to 7.8072 , lower than the recommended threshold of 10 [114], representing that the severe multicollinearity among the variables is absent.

Third, to evaluate the formative construct's discriminant validity, we computed and compared the item-to-item, construct-to-construct, item-to-its formative construct, and item-to-other constructs correlations [115]. We found that the inter-item correlations $(0.8595)$ tend to be higher than inter-construct correlations (0.5313). Additionally, the correlation between the formative item and its composite structure (0.8871) is higher than the correlation with other structures (0.4545). Collectively, these results provide persuasive evidence of adequate discriminant validity for UES.

Fourth, we tested the nomological validity of UES by correlating it with other constructs in our research model which should theoretically be correlated. Table 7 shows that UES has a positively significant relationship with the four outcome variables, indicating the nomological validity of measurement.

Table 7. The $\mathrm{R}^{2}$ and $\mathrm{Q}^{2}$ of endogenous constructs.

\begin{tabular}{ccc}
\hline Construct & $\mathbf{R}^{\mathbf{2}}$ & $\mathbf{Q}^{\mathbf{2}}$ \\
\hline EA & 0.0157 & 0.0118 \\
SN & 0.0445 & 0.0332 \\
ESE & 0.0428 & 0.0356 \\
EI & 0.8056 & 0.6519
\end{tabular}

Note: EA = entrepreneurial attitude; $\mathrm{SN}$ = subjective norms; ESE = entrepreneurial self-efficacy; EI = entrepreneurial intention.

\subsubsection{Structural Model}

The primary assessment contents of the structural model include goodness of fit (GoF), explained variance $\left(R^{2}\right)$, the capability to predict $\left(Q^{2}\right)$, the path coefficients' level and significance, and robustness test of measurement results.

First, although PLS-SEM does not offer overall model fit statistics like CB-SEM, researchers have started to calculate the GoF when using PLS path modeling [116], which is defined as the geometric mean of the average communality and average $\mathrm{R}^{2}$ for the endogenous constructs. To verify our research model's overall fit quality, we computed the GoF value following [116]. Because communality equals AVE in the PLS path modeling, we substituted AVE and $R^{2}$ values into the GoF calculation formula $\left(\mathrm{GoF}=\sqrt{\overline{\text { communality }} \times \overline{R^{2}}}\right)$, obtained the GoF value of $0.4252(\mathrm{GoF}=\sqrt{0.7958 \times 0.2272}=0.4252)$, which exceeds the cut-off value of 0.36 recommended by Wetzels et al. [117], and indicates that our model is very suitable. 
Second, we checked the endogenous latent variables' explained variance. Table 7 shows that the endogenous constructs' $\mathrm{R}^{2}$ are $0.0157,0.0445,0.0428$, and 0.8056 for EA, SN, ESE, and EI, respectively, which means that our model has a relatively high explanatory power for entrepreneurial intentions [102]. More specifically, $80.56 \%$ of the variance in the entrepreneurial intentions construct can be explained by UES, EA, SN, and ESE.

Third, to test the structural model's predictive capability for endogenous latent variables, the Stone-Geisser $\mathrm{Q}^{2}$ values were calculated using the blindfolding procedures [116]. As shown in Table 7, $\mathrm{Q}^{2}$ values for the EA, SN, ESE, and EI are larger than zero, suggesting our model has sufficient predictive power for endogenous latent variables. Besides that, the $\mathrm{Q}^{2}$ value of EI (0.6519) is greater than the 0.35 threshold, indicating that our model has strong predictive relevance to EI [118].

Next, to test the research hypotheses, we assessed each path coefficient's significance using a bootstrap procedure with $\mathrm{N}=5000$ samples. Table 8 and Figure 2 depict the structural model results generated with bootstrap. According to the t-statistics and the $95 \%$ confidence interval, all path coefficients are significant at the 0.001 level, indicating that all hypotheses are supported. UES is positively related to EI $(\beta=0.0174, p<0.001)$, supporting Hypothesis 1 . UES has a positive impact on EA $(\beta=0.1252, p<0.001)$, SN $(\beta=0.2109$, $p<0.001)$, and ESE $(\beta=0.2068, p<0.001)$, supporting Hypotheses 2,3 , and 4 . In addition EA $(\beta=0.6735, p<0.001)$, SN $(\beta=0.1052, p<0.001)$, and ESE $(\beta=0.1671, p<0.001)$ positively affect EI, supporting Hypotheses 5, 6, and 7. Additionally, we also used the bootstrap method suggested by Shrout and Bolger [119] to test EA, SN, and ESE's mediation effect in the relationship between UES and EI. The test results (Table 9) suggest that all the $95 \%$ bias-corrected confidence interval for the UES-EA-EI, UES-SN-EI, UES-ESE-EI excluded zero, with a two-tailed significance value of less than 0.001, thus supporting Hypotheses 8, 9, and 10.

Finally, to prove our research results' robustness, we followed the practice of Ahuja et al. [120], using the bootstrapping procedures with 1000, 3000, and 5000 times of resampling to test the results. The results show that the path coefficient magnitude and significance obtained using different resampling rounds are quite robust. In addition, we compared the Ordinary Least Square (OLS) regression results with the PLS results [115]. As shown in Tables 8 and 9, the OLS regression results are basically in line with the PLS results, which further supports the credibility and robustness of our research results.

Table 8. Results of direct effects and robustness test.

\begin{tabular}{|c|c|c|c|c|c|c|c|c|c|}
\hline \multirow{2}{*}{ Hypothesis } & \multirow[b]{2}{*}{ Path } & \multicolumn{4}{|c|}{ PLS Result } & \multicolumn{3}{|c|}{ OLS Regression Result } & \multirow[b]{2}{*}{ Results } \\
\hline & & Coefficient & T-Stat & $95 \%$ CI & $p$-Value & Coefficient & T-Stat & $p$-Value & \\
\hline H1 & UES-EI & 0.0174 & 4.0091 & $(0.009,0.0259)$ & 0.0001 & 0.009 & 2.269 & 0.023 & Supported \\
\hline $\mathrm{H} 2$ & UES-EA & 0.1252 & 12.8909 & $(0.1071,0.1452)$ & 0.0000 & 0.115 & 13.728 & 0.0000 & Supported \\
\hline H3 & UES-SN & 0.2109 & 21.7385 & $(0.1922,0.2301)$ & 0.0000 & 0.203 & 24.515 & 0.0000 & Supported \\
\hline $\mathrm{H} 4$ & UES-ESE & 0.2068 & 21.3133 & $(0.1882,0.2264)$ & 0.0000 & 0.198 & 23.848 & 0.0000 & Supported \\
\hline H5 & EA-EI & 0.6735 & 79.7957 & $(0.6569,0.6899)$ & 0.0000 & 0.651 & 98.271 & 0.0000 & Supported \\
\hline H6 & SN-EI & 0.1052 & 12.8053 & $(0.0888,0.1216)$ & 0.0000 & 0.12 & 19.109 & 0.0000 & Supported \\
\hline H7 & ESE-EI & 0.1671 & 20.3878 & $(0.1512,0.1833)$ & 0.0000 & 0.176 & 27.083 & 0.0000 & Supported \\
\hline
\end{tabular}

Note: UES = university entrepreneurship support; EI = entrepreneurial intention; EA = entrepreneurial attitude; $\mathrm{SN}$ = subjective norms; $\mathrm{ESE}=$ entrepreneurial self-efficacy.

Table 9. Results of mediation effect test and robustness test.

\begin{tabular}{cccccccc}
\hline \multirow{2}{*}{ Hypothesis } & \multirow{2}{*}{ Path } & Coefficient & Bias-Corrected 95\% CI & $\boldsymbol{p}$-Value & Coefficient & $\boldsymbol{p}$-Value & Results \\
& & UES-EA-EI & 0.0843 & $(0.0704,0.0965)$ & 0.0000 & 0.101 & 0.0000 \\
H8 & UES-SN-EI & 0.0222 & $(0.0184,0.0263)$ & 0.0000 & 0.021 & 0.0000 & Supported \\
H9 & UES-ESE-EI & 0.0346 & $(0.0301,0.0391)$ & 0.0000 & 0.030 & 0.0000 & Supported \\
H10 & UEsted \\
\hline
\end{tabular}

Note: UES = university entrepreneurship support; EI = entrepreneurial intention; EA = entrepreneurial attitude; $\mathrm{SN}$ = subjective norms; $\mathrm{ESE}=$ entrepreneurial self-efficacy. 


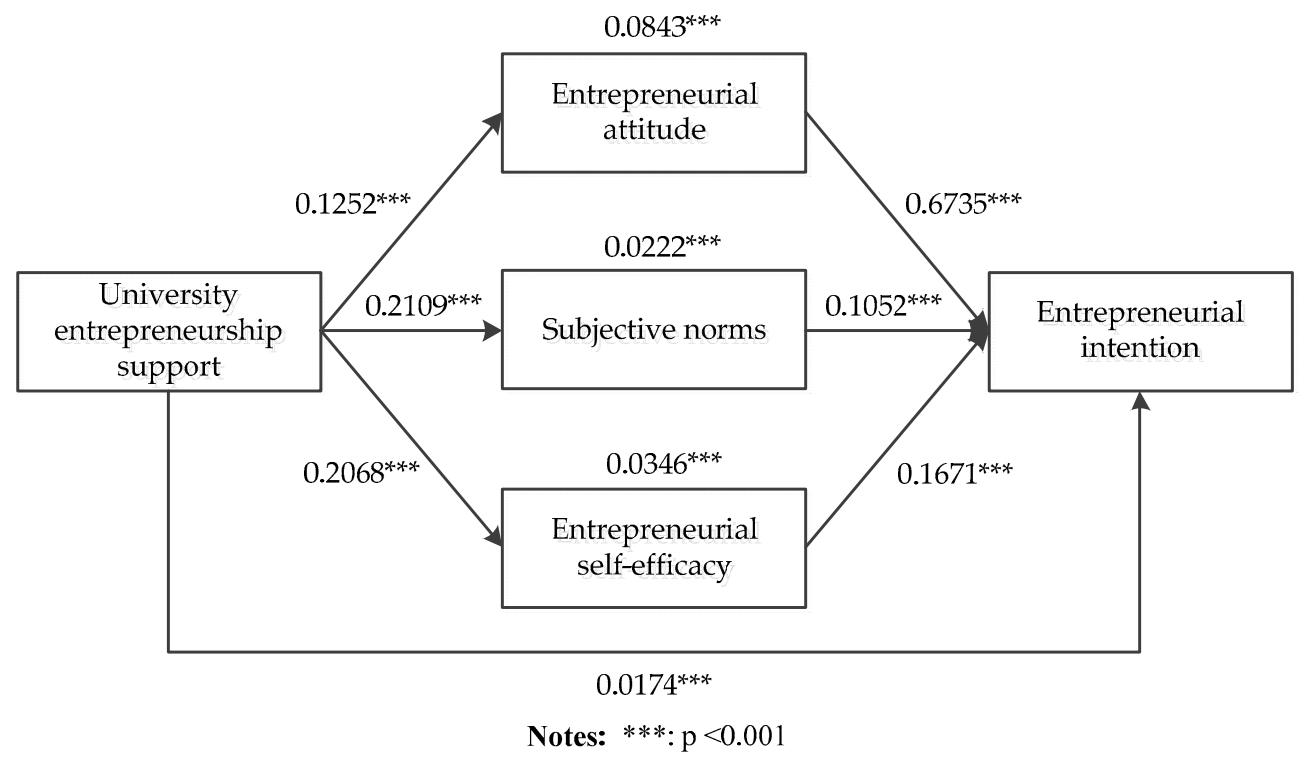

Figure 2. Influences of university entrepreneurship support on entrepreneurial intention.

\section{Discussion and Implications}

\subsection{Discussion}

This study's main aim is to assess the evaluation of college graduates on entrepreneurship support they received from their universities and its influence mechanism on their entrepreneurial intentions so as to help universities improve their entrepreneurship support measures and encourage more students to start their businesses after graduation. To this end, this study develops a model that combines EA, SN, and ESE; and utilizes a large sample of survey data from China to examine students' evaluation of UES and its impact on college graduates' EI.

Our findings demonstrate that students are not very satisfied with the various UES, which include entrepreneurship education $(M=2.95)$, entrepreneurial climate $(M=2.95)$, entrepreneurial management measures $(M=3.07)$, entrepreneurial training conditions $(\mathrm{M}=3.05)$, and other entrepreneurial services $(\mathrm{M}=3.02)$. The possible reasons for this result can be explained from the following three aspects: first, in terms of the quantity of UES, it may be due to the lack of teachers, funds, and other practical training conditions [121], some universities have not or rarely provided students with additional necessary entrepreneurial support besides opening entrepreneurship courses following the requirements of the Chinese Ministry of Education. Second, from the perspective of the quality of UES, one possible explanation is that universities offer a wide variety of support, based on the assumed demand for entrepreneurship activities. Students have no direct control over the specific content of UES, although they have the right to submit feedback and suggestions freely. The choice of entrepreneurship support programs rests in the hands of the university's entrepreneurial management department. Another possible explanation is that the university deems students as a homogeneous group when providing various entrepreneurial supports and does not fully consider students' individual needs, and therefore has not provided more targeted entrepreneurial support. Additionally, another explanation is that this may be related to problems in entrepreneurship education. Some scholars asserted that entrepreneurship education in Chinese universities has issues such as irrational curriculum settings, putting too much emphasis on theory and neglect of practice, and insufficient integration of entrepreneurship education and professional education [122]. These problems may reduce the effect of entrepreneurship education, thus failing to achieve the expected impact of students' satisfaction. Third, from the students' perspective, students who are not satisfied might have overly high expectations of UES. The expectation is regarded as a kind of psychological activity, and satisfaction 
can be understood as individuals' subjective feeling based on the comparison between expectation and reality. If the UES does not meet student expectations, they are unlikely to agree with the UES and make follow-up commitments entirely. Therefore, in this sense, it is understandable that graduates are not very satisfied with UES. This finding may disappoint policymakers and university administrators. Still, it gives a wake-up call for the higher education system in China to rethink the rationality of various related entrepreneurship supports to create better support systems to encourage students to regard entrepreneurship as a viable career option.

As predicted, our hypothesis test result shows that UES weakly and positively affects EI $\left(\mathrm{H} 1, \beta=0.0174^{* * *}\right)$. This suggests that independently from three motivational antecedents of intention, a more favorable university environment, and support system leads to higher entrepreneurial intentions. The result is in contradiction with several prior studies. A survey of 1530 German university students by Walter et al. showed that university entrepreneurship support programs, including entrepreneurial competitions, financial support, etc., are not significantly related to entrepreneurial intentions [15]. Another two surveys conducted in Turkey also prove that the university environment is insignificant $[123,124]$. However, our finding is in concordance with other studies that found that a favorable university entrepreneurial environment and support will stimulate students' EI. For instance, a survey study from Austria found that students' positive views on the university environment are positively correlated with entrepreneurial intentions $(\beta=0.066, p<0.001)$ [19]. Nasiru et al.'s study on 595 college students in Nigeria also found that the perceived university support is positively related to entrepreneurial intentions [62]. Moreover, similar empirical investigations conducted in Brazil [125], Vietnam [63], and Pakistan [20] also reported the same conclusion. The reasons for this mixed result may be manifold, so we encourage multi-country comparative studies to further confirm their relationship.

Additionally, the influence of UES on the three antecedents of behavioral intention is examined. First, in contrast to the results of previous empirical studies, Trivedi's crosscultural analysis showed that university environment and support negatively influence students' EA [26], while we find that UES exerts a significant positive influence on EA (H2, $\left.\beta=0.1252^{* * *}\right)$. It means a positive university environment and support play a pivotal part in shaping graduates' desires and mentality. Obviously, the result of this study is in line with theoretical expectations, since in addition to the argument that individual attitudes can be altered in the interaction with the university environment and other people, organizational support theory also emphasizes that positive attitudes can be shaped by the sense of protection that is generated from organizations [126]. Secondly, the positive impact of UES on SN $\left(\mathrm{H} 3, \beta=0.2109^{* * *}\right)$ is one of our most important findings because in previous studies, as far as we know, almost no one examined the direct impact of UES on SN, and our research fills this gap. This positive effect means that the encouragement of entrepreneurship by universities and essential groups such as mentors, classmates, and alumni can indeed improve SN. Finally, consistent with previous similar investigations, we verify the opinion that UES is positively related to ESE $\left(\mathrm{H} 4, \beta=0.2068^{* * *}\right)$. The difference, however, is that the effect sizes are different from study to study. For example, Saeed et al., based on 805 college students in Pakistan, showed that the impact of three types of UES on EI is 0.37, 0.34 , and 0.32 , respectively, with an average effect of 0.34 [25]. Also, in Pakistan's context, Islam's survey of 245 college students found the effect value of 0.29 [20]. In comparison, Trivedi's analysis of the data of 1097 post-graduate students in India, Malaysia, and Singapore showed that the effect size is only 0.069 [26]. A large part of this difference may be due to cultural context, variable measurement, and sample issues. It is encouraging that although our research context and variable measurements are not comparable to the above studies, the sample size of this study $(\mathrm{N}=13,954)$ is sufficient to provide solid evidence for the relationship between UES and ESE.

Consistent with theory and prior research results [127-129], the three motivational antecedents (EA, SN, and ESE) positively influence students' EI. Among them, EA is the 
most important in predicting and developing students' EI $\left(\mathrm{H} 5, \beta=0.6735^{* * *}\right)$, followed by ESE $\left(H 7, \beta=0.1671^{* * *}\right)$, and SN $\left(\mathrm{H} 6, \beta=0.1052^{* * *}\right)$. The finding that EA has the strongest predictor of EI is consistent with the research of $[126,130,131]$ but different from the results of $[127,132]$, they respectively found that SN and ESE have the greatest influence. This could be interpreted if we consider the similarity between the concepts of EA and EI. In the entrepreneurial literature, several researchers assert that EI is an individual's attitude towards whether to engage in entrepreneurial activities [59,133]. In this sense, it is not surprising that attitude is found as the strongest predictor of EI. These results indicate that if public policy and university administration hope to increase graduates' entrepreneurial intentions, SN, and ESE, especially the improvement of EA is apparently an effective lever.

Furthermore, our study also provides preliminary empirical evidence for the influence mechanism of UES on EI. The results suggest that EA, SN, and ESE play a mediating role between UES and EI. This finding is in line with the theoretical prediction of TPB as the distal variable (e.g., UES) on EI is mediated through EA, SN, and ESE. That is, UES not only directly affects EI, but also indirectly affects EI through EA (H8, $\left.\beta=0.0843^{* * *}\right)$, SN (H9, $\left.\beta=0.0222^{* * *}\right)$, and ESE $\left(\mathrm{H} 10, \beta=0.0346^{* * *}\right)$. Thus, affirming that the graduates' perceived university' entrepreneurial environment and support system has a significant effect on graduates' intention to start a new business.

\subsection{Implications}

\subsubsection{Theoretical Implications}

This study mainly contributes to the emerging entrepreneurship literature from the following three fronts. First, we answer Fayolle and Liñán's [134] call for the further study of the role of context and institutions in EI, providing substantial evidence from China for the world literature by a large-scale annual survey data, while previous similar studies focus on countries such as Singapore and Germany. Second, the direct effect of UES on students' EA, ESE, and EI, as well as the mediating effect of ESE have been examined in previous studies but have neglected to account for the impact of UES on SN and the mediating role of EA and SN. Therefore, this study's uniqueness is that, in addition to testing the direct effects, it also takes a critical step forward, linking UES with the three antecedents of behavioral intentions to examine the impact mechanism and has drawn several important conclusions. These results suggest that UES directly and positively affects EI. EA, SN, and ESE serve as the mediating roles between UES and EI. Third, we confirm the effectiveness and importance of EA, SN, and ESE in predicting EI in the Chinese context by adding UES as the three motivations' exogenous factor.

\subsubsection{Practical Implications}

Undoubtedly, our findings also have several implications for practice. First, given that our study shows that students are less than satisfied with the various UES, starting from several possible reasons, universities should concentrate more on the availability and quality of UES, respect the students' specific needs and expectations, listen to their suggestions, regularly evaluate the extent of their support and its impact on students, clarify the strengths and weaknesses of current entrepreneurial supports, and take targeted measures to improve students' satisfaction with their entrepreneurial supports.

Second, the direct impact of UES on EI suggests that if policymakers and university administrators want to enhance students' entrepreneurial intentions, they should focus more on providing students with a supportive university entrepreneurial environment. Specifically, given the current shortcomings of Chinese UES, such as lack of teachers, funds, and other practical training conditions [121], irrational entrepreneurship curriculum settings, and entrepreneurial education putting too much emphasis on theory and neglect of practice [122], universities can seek support from the government, alumni, and social forces to overcome resource limitations, and reasonably arrange education programs. Additionally, they can create a platform for students to communicate and contact alumni entrepreneurs, technical experts, legal counsels, etc. so that they could use this low-density 
social network to recognize and pursue entrepreneurial opportunities [135] and practice their entrepreneurial ideas.

Third, UES has been proven to positively affect EA, SN, and ESE, which in turn have a positive influence over EI. In addition, EA, SN, and ESE play a mediating role between UES and EI. Thus, universities should consider designing policies and programs from the three aspects of EA, SN, and ESE, to improve students' EI. Specifically, an important determinant of attitude is outcome expectations, thus universities can consider adopting the following suggestions to improve students' EA: reduce students' aversion to the possible negative outcomes of entrepreneurial activities (entrepreneurial failure) by publicizing government and universities' policies and measures such as the entrepreneurial activity funds and loans. Use entrepreneurial education and set role models to enhance students' expectations for entrepreneurial success's positive outcomes such as independence, wealth, and ownership. Additionally, in terms of $\mathrm{SN}$, it is recommended that on the one hand, universities strive to create a strong entrepreneurial climate and fully demonstrate the social desirability for college students' entrepreneurship; on the other hand, sending brochures and emails allows and encourages important reference people, together with students, to participate in entrepreneurship courses and entrepreneurship competition exhibition activities organized by the university to increase the understanding and support of important groups for students' entrepreneurship, thereby to improve their SN. Finally, to foster students' ESE, universities can provide them with appropriate knowledge, listen to guest speakers, set alumni entrepreneurial role models, and increase entrepreneurial practice opportunities (e.g., business simulations, case studies, startup workshops, competitions, or leagues, and entrepreneurship internships), and make them believe that they have enough ability to carry out entrepreneurial activities.

\section{Limitations and Future Directions}

Admittedly, our research has some limitations. First, like most studies in the entrepreneurial literature, this study's results rely on cross-sectional data from a province in China. Therefore, caution should be exercised when extending the findings in other contexts and comparing them with related longitudinal research results. Second, we are interested in the impact of UES on students' EI rather than actual behavior. Consequently, our research cannot show how many students initiate entrepreneurial activities under UES's influence. Third, for this study, we primarily focus on the impact of UES on college students' EI while ignoring other potentially influential factors. Fourth, the measurement of UES is imperfect. Although we use five dimensions to measure UES, each dimension has only one item, which may cause us to be unable to capture the specific differences in the entrepreneurial support levels of different universities more accurately. Fifth, this study may also be threatened by self-reporting bias; in particular, the SN and ESE may be biased since respondents may not be clear about the opinions of significant reference people on their entrepreneurship, and they may also overstate their perceived ability to carry out entrepreneurial activities.

It must be acknowledged that there is much to be done in this field. First, to address this limitation of cross-sectional data, future researchers are advised to conduct longitudinal surveys to deepen our understanding of the relationship between UES, EI, and entrepreneurial behavior. Second, our research results can only be extended to similar societies. Future researchers could expand the investigation's scope and do some cross-cultural comparative studies to find more interesting results to increase the model's generalization and external validity. Third, future research may consider understanding the formation of EI from an integrated framework that includes UES factors, individual student factors, family factors, and social factors, and explore the interrelationships between them. Fourth, in terms of measuring UES, using multiple indicators and more refined ways would obtain more precise results and lead to a better understanding of its impact on entrepreneurial intentions. Fifth, future studies could collect data directly from the potential entrepreneurs' significant others to improve subjective normative measurement 
accuracy. Additionally, apart from self-reported self-efficacy, an individual's ability to accomplish entrepreneurial tasks can be evaluated by experts based on an individual's performance in business simulation and entrepreneurial internships, which may be valuable for overcoming the subjectivity of the ESE score.

\section{Conclusions}

This study examines students' assessment of UES and its impact on college graduates' EI using a large sample of survey data from China. The empirical analysis demonstrates that students' satisfaction with UES needed to be further improved in the future; UES has a direct positive effect on students' EI, although not a very strong relationship. Moreover, UES also positively influences EA, SN, and ESE, which in turn determines EI. The results also reveal that EA, SN, and ESE mediate the relationship between UES and EI. Despite several limitations, this study makes significant contributions to the existing entrepreneurial literature and practice and points to the directions for future research in this field.

Author Contributions: Y.S. wrote and revised the paper. G.L. reviewed the paper. B.P. participated in the questionnaire design and data collection process and provided suggestions for the revision of this article. All authors have read and agreed to the published version of the manuscript.

Funding: The research was supported by the National Natural Science Foundation of China General Program [71573203]; Humanities and Social Science Research Foundation Project of the Ministry of Education [18YJC880069]; Shaanxi Provincial Social Science Foundation Project [2017P017].

Institutional Review Board Statement: Not applicable.

Informed Consent Statement: Informed consent was obtained from all subjects involved in the study.

Data Availability Statement: The raw/processed data required to reproduce these findings cannot be shared at this time as the data also forms part of an ongoing study.

Acknowledgments: We would like to thank Jianli Xie of the School of Management at Xi'an Jiaotong University, for her helpful suggestions about an earlier version of the article.

Conflicts of Interest: The authors declare no conflict of interest.

\section{References}

1. Veciana, J. Theory and policy of business creation. In Jornada Dels Economistes; ESP: Barcelona, Spain, 1998.

2. Sieger, P.; Fueglistaller, U.; Zellweger, T. Student Entrepreneurship across the Globe: A Look at Intentions and Activities. Available online: https:/ /www.guesssurvey.org/PDF/2013/GUESSS_INT_2013_REPORT.pdf (accessed on 25 October 2020).

3. Mycos. Chinese College Graduates' Employment Annual Report. 2019. Available online: http://www.199it.com/archives/9306 84.html (accessed on 25 October 2020).

4. Farashah, A.D. The effects of demographic, cognitive and institutional factors on development of entrepreneurial intention: Toward a socio-cognitive model of entrepreneurial career. J. Int. Entrep. 2015, 13, 452-476. [CrossRef]

5. Reissová, A.; Šimsová, J.; Sonntag, R.; Kučerová, K. The influence of personal characteristics on entrepreneurial intentions: International comparison. Entrep. Bus. Econ. Rev. 2020, 8, 29-46.

6. Zhao, H.; Seibert, S.E.; Lumpkin, G.T. The Relationship of Personality to Entrepreneurial Intentions and Performance: A MetaAnalytic Review. Entrep. Res. J. 2015, 36, 381-404. [CrossRef]

7. Karyaningsih, R.P.D.; Wibowo, A.; Saptono, A.; Narmaditya, B.S. Does entrepreneurial knowledge influence vocational students' intention? Lessons from Indonesia. Entrep. Bus. Econ. Rev. 2020, 8, 138-155.

8. Carr, J.C.; Sequeira, J.M. Prior family business exposure as intergenerational influence and entrepreneurial intent: A Theory of Planned Behavior approach. J. Bus. Res. 2007, 60, 1090-1098. [CrossRef]

9. Taylor, M.P. Earnings, Independence or Unemployment: Why Become Self-Employed? Oxf. Bull. Econ. Stat. 1996, 58, 253-266. [CrossRef]

10. Wagner, J.; Sternberg, R. Start-up activities, individual characteristics, and the regional milieu: Lessons for entrepreneurship support policies from German microdata. Ann. Reg. Sci. 2004, 38, 219-240. [CrossRef]

11. Wilson, F.; Kickul, J.; Marlino, D. Gender, entrepreneurial self-efficacy, and entrepreneurial career intentions: Implications for entrepreneurship education. Entrep. Theory Pract. 2007, 31, 387-406. [CrossRef]

12. Martin, B.C.; McNally, J.J.; Kay, M.J. Examining the formation of human capital in entrepreneurship: A meta-analysis of entrepreneurship education outcomes. J. Bus. Ventur. 2013, 28, 211-224. [CrossRef]

13. Vodă, A.I.; Florea, N. Impact of personality traits and entrepreneurship education on entrepreneurial intentions of business and engineering students. Sustainability 2019, 11, 1192. [CrossRef] 
14. Kraaijenbrink, J.; Bos, G.; Groen, A. What Do Students Think of the Entrepreneurial Support Given by Their Universities? Int. J. Entrep. Small Bus. 2010, 9, 110-125. [CrossRef]

15. Walter, S.G.; Parboteeah, K.P.; Walter, A. University Departments and Self-Employment Intentions of Business Students: A CrossLevel Analysis. Entrep. Theory Pract. 2013, 37, 175-200. [CrossRef]

16. Shen, T.; Osorio, A.E.; Settles, A. Does Family Support Matter? The Influence of Support Factors on Entrepreneurial Attitudes and Intentions of College Students. Acad. Entrep. J. 2017, 23, 24-43.

17. Lüthje, C.; Franke, N. The 'making' of an entrepreneur: Testing a model of entrepreneurial intent among engineering students at MIT. RED Manag. 2003, 33, 135-147.

18. Turker, D.; Selcuk, S.S. Which factors affect entrepreneurial intention of university students? J. Eur. Ind. Train. 2009, 33, 142-159. [CrossRef]

19. Schwarz, E.J.; Wdowiak, M.A.; Almer-Jarz, D.A.; Breitenecker, R.J. The effects of attitudes and perceived environment conditions on students' entrepreneurial intent: An Austrian perspective. Educ. Train. 2009, 51, 272-291. [CrossRef]

20. Islam, T. Cultivating Entrepreneurs: Role of the University Environment, Locus of Control and Self-efficacy. Proc. Comput. Sci. 2019, 158, 642-647. [CrossRef]

21. Ministry of Education, China. Opinions of the State Council on Several Policies and Measures for Vigorously Promoting Mass Entrepreneurship and Innovation. Available online: http://www.gov.cn/zhengce/content/2015-06/16/content_9855.htm (accessed on 22 February 2021).

22. Ministry of Education, China. Opinions of the State Council on Promoting the High-Quality Development of Innovation and Entrepreneurship and Creating an Upgrading Version of "Double Entrepreneurship". Available online: http://www.gov.cn/ zhengce/content/2018-09/26/content_5325472.htm (accessed on 22 February 2021).

23. Editorial Board. National Undergraduate Education Teaching Quality Report (2017); Higher Education Press: Beijing, China, 2019.

24. Editorial Board. National Undergraduate Education Teaching Quality Report (2018); Working Manuscript; Higher Education Press: Beijing, China, 2020.

25. Saeed, S.; Yousafzai, S.Y.; Yani-De-Soriano, M.; Muffatto, M. The Role of Perceived University Support in the Formation of Students' Entrepreneurial Intention. J. Small Bus. Manag. 2015, 53, 1127-1145. [CrossRef]

26. Trivedi, R. Does university play significant role in shaping entrepreneurial intention? A cross-country comparative analysis. J. Small Bus. Enterp. Dev. 2016, 23, 790-811. [CrossRef]

27. Zamrudi, Z.; Yulianti, F. Sculpting Factors of Entrepreneurship among University Students in Indonesia. Entrep. Bus. Econ. Rev. 2020, 8, 33-49. [CrossRef]

28. Shaver, K.G. The entrepreneurial personality myth. Bus. Econ. Rev. 1995, 41, 20-22.

29. Ripsas, S. Towards an Interdisciplinary Theory of Entrepreneurship. Small Bus. Econ. 1998, 10, 103-115. [CrossRef]

30. Gartner, W.B. A Conceptual Framework for Describing the Phenomenon of New Venture Creation. Acad. Manag. Rev. 1985, 10, 696-706. [CrossRef]

31. Khuong, M.N.; An, N.H. The Factors Affecting Entrepreneurial Intention of the Students of Vietnam National University-A Mediation Analysis of Perception toward Entrepreneurship. J. Bus. Econ. Manag. 2016, 4, 104-111. [CrossRef]

32. Carsrud, A.L.; Brännback, M. Toward A Contextual Model of Entrepreneurial Intentions; Springer: New York, NY, USA, 2009.

33. Shapero, A.; Sokol, L. The social dimensions of entrepreneurship. In Encyclopedia of Entrepreneurship; Prentice-Hall: Englewood Cliffs, NJ, USA, 1982; pp. 72-90.

34. Ajzen, I. The theory of planned behavior. Organ. Behav. Hum. Decis. Process. 1991, 50, 179-211. [CrossRef]

35. Krueger, N.F.; Brazeal, D.V. Entrepreneurial potential and potential entrepreneurs. Enterp. Theory Pract. 1994, 19, 91-104. [CrossRef]

36. Peterman, N.E.; Kennedy, J. Enterprise education: Influencing students' perceptions of entrepreneurship. Enterp. Theory Pract. 2003, 28, 129-144. [CrossRef]

37. Schlaegel, C.; Koenig, M. Determinants of entrepreneurial intent: A meta analytic test and integration of competing models. Enterp. Theory Pract. 2014, 38, 291-332. [CrossRef]

38. Shepperd, B.H.; Hartwick, J.; Warshaw, P.R. The theory of reasoned action: A meta-analysis of past research with recommendations for modiŽ cations and future research. J. Consum. Res. 1988, 15, 325-343. [CrossRef]

39. Veciana, J.M.; Aponte, M.; Urbano, D. University students' attitudes towards entrepreneurship: A two countries comparison. Int. Entrep. Manag. J. 2005, 1, 165-182. [CrossRef]

40. Sparks, P.; Shepherd, R.; Wieringa, N.; Zimmermans, N. Perceived behavioural control, unrealistic optimism and dietary change: An exploratory study. Appetite 1995, 24, 243-255. [CrossRef]

41. Elfving, J.; Brännback, M.; Carsrud, A. Understanding the Entrepreneurial Mind: Opening the Black Box; Springer: Berlin/Heidelberg, Germany, 2009; pp. 23-33.

42. Zampetakis, L.A.; Lerakis, M.; Kafetsios, K.; Moustakis, V.S. The moderating role of anticipated affective ambivalence in the formation of entrepreneurial intentions. Int. Entrep. Manag. J. 2015, 6, 1-13. [CrossRef]

43. Godin, G.; Kok, G. The theory of planned behavior: A review of its applications to health-related behaviors. Am. J. Health Promot. 1996, 11, 87-98. [CrossRef]

44. Bandura, A. Health promotion from the perspective of social cognitive theory. Psychol. Health 1998, 13, 623-649. [CrossRef]

45. Ajzen, I. Perceived behavioral control, self-efficacy, locus of control, and the theory of planned behavior. J. Appl. Soc. Psychol. 2002, 32, 1-20. [CrossRef] 
46. Terry, D.J.; O'Leary, J.E. The theory of planned behaviour: The effects of perceived behavioural control and self-efficacy. Br. J. Soc. Psychol. 1995, 34, 199-220. [CrossRef]

47. Manstead, A.S.R.; van Eekelen, S.A.M. Distinguishing between perceived behavioral control and self-efficacy in the domain of academic intentions and behaviors. J. Appl. Soc. Psychol. 1998, 28, 1375-1392. [CrossRef]

48. Armitage, C.I.; Conner, M. Distinguishing perceptions of control from self-efficacy: Predicting consumption of a low-fat diet using the theory of planned behavior. J. Appl. Soc. Psychol. 1999, 29, 72-90. [CrossRef]

49. De Vries, H.; Dijkstra, M.; Kuhlman, P. Self-efficacy: The third factor besides attitude and subjective norm as a predictor of behavioural intentions. Health Educ. Res. 1988, 3, 273-282. [CrossRef]

50. Sullivan, A.M.; Johnson, B.; Owens, L.; Conway, R. Punish Them or Engage Them? Teachers' Views of Unproductive Student Behaviours in the Classroom. Austr. J. Teach. Educ. 2014, 39, 43-56. [CrossRef]

51. Fetters, M.L.; Greene, P.G.; Rice, M.P. The Development of University-Based Entrepreneurship Ecosystems: Global Practices; Edward Elgar: Cheltenham, UK, 2010.

52. Morris, M.H.; Shirokova, G.; Tsukanova, T. Student entrepreneurship and the university ecosystem: A multi-country empirical exploration. Eur. J. Int. Manag. 2017, 11, 65. [CrossRef]

53. Bird, B.J. Implementing entrepreneurial ideas: The case for intention. Acad. Manag. Rev. 1988, 13, 442-453. [CrossRef]

54. Bandura, A. Social Cognitive Theory: An Agentic Perspective. Int. Adv. Econ. Res. 2007, 13, 443-453.

55. Aldrich, H.E.; Martinez, M.A. Many are called, but few are chosen: An evolutionary perspective for the study of entrepreneurship. Enterp. Theory Pract. 2001, 25, 41-56. [CrossRef]

56. Choo, S.; Wong, M. Entrepreneurial intention: Triggers and barriers to new venture creations in Singapore. Singap. Manag. Rev. 2006, 28, 47-64.

57. $\mathrm{Wu}, \mathrm{S}$.; $\mathrm{Wu}, \mathrm{L} . \mathrm{F}$. The impact of higher education on entrepreneurial intentions of university students in China. J. Small Bus. Enterp. Dev. 2008, 15, 752-774. [CrossRef]

58. Phan, P.H.; Wong, K.; Wang, C.K. Antecedents to entrepreneurship among university students in Singapore: Beliefs, attitudes and background. J. Enterp. Cult. 2002, 10, 151-174. [CrossRef]

59. Krueger, N.F. The Impact of Prior Entrepreneurial Exposure on Perceptions of New Venture Feasibility and Desirability. Enterp. Theory Pract. 1993, 18, 5-21. [CrossRef]

60. Granovetter, M. Economic Action and Social Structure: The Problem of Embeddedness. Am. J. Soc. 1985, 91, 481-510. [CrossRef]

61. Franke, N.; Lüthje, C. Entrepreneurial intentions of business students: A benchmarking study. Int. Innov. Technol. Manag. 2004, 1, 269-288. [CrossRef]

62. Nasiru, A.; Keat, O.Y.; Bhatti, M.A. Influence of Perceived University Support, Perceived Effective Entrepreneurship Education, Perceived Creativity Disposition, Entrepreneurial Passion for Inventing and Founding on Entrepreneurial Intention. Mediterr. J. Soc. Sci. 2015, 6, 88-95. [CrossRef]

63. Nguyen, T. The Impact of Access to Finance and Environmental Factors on Entrepreneurial Intention: The Mediator Role of Entrepreneurial Behavioural Control. Entrep. Bus. Econ. Rev. 2020, 8, 127-140. [CrossRef]

64. Sampedro, I.R.; Fernández-Laviada, A.; Crespo, A.H. Entrepreneurial intention: Perceived advantages and disadvantages. Acad. Rev. Latinoam. Adm. 2014, 27, 284-315. [CrossRef]

65. Mueller, S.L. Gender gaps in potential for entrepreneurship acrosss countries and cultures. J. Dev. Entrep. 2004, 9, $199-220$.

66. Gelderen, M.V.; Brand, M.; Praag, M.V.; Bodewes, W.; Poutsma, E.; Gils, A.V. Explaining Entrepreneurial Intentions by Means of the Theory of Planned Behavior. Career Dev. Int. 2008, 13, 538-559. [CrossRef]

67. Ajzen, I. Nature and operation of attitudes. Ann. Rev. Psychol. 2001, 52, 27-58. [CrossRef] [PubMed]

68. Ajzen, I.; Fishbein, M. Understanding Attitudes and Predicting Social Behavior; Prentice-Hall: Englewood Cliffs, NJ, USA, 1980.

69. Bandura, A. Self-Efficacy: The Exercise of Control; W.H. Freeman: New York, NY, USA, 1997.

70. Bandura, A. Social Learning Theory; Prentice Hall: Englewood Cliffs, NJ, USA, 1977.

71. Usher, E.L.; Pajares, F. Sources of self-efficacy in school: Critical review of the literature and future directions. Rev. Educ. Res. 2008, 78, 751-796. [CrossRef]

72. Maresch, D.; Harms, R.; Kailer, N.; Wimmer-Wurm, B. The impact of entrepreneurship education on the entrepreneurial intention of students in science and engineering versus business studies university programs. Technol. Forecast. Soc. Chang. 2016, 104, 172-179. [CrossRef]

73. Mahfud, T.; Triyono, M.B.; Sudira, P.; Mulyani, Y. The influence of social capital and entrepreneurial attitude orientation on entrepreneurial intentions: The mediating role of psychological capital. Eur. Res. Manag. Bus. Econ. 2020, 26, 33-39. [CrossRef]

74. Ajzen, I. Attitudes, traits and actions: Dispositional prediction of behaviour in personality and social psychology. Adv. Exp. Soc. Psychol. 1987, 20, 1-63.

75. Thomas, A.; Passaro, R.; Scandurra, G. The Perception of the Contextual Factors as Predictor of Entrepreneurial Intent: Evidences from an Empirical Survey. J. Enterp. Cult. 2014, 22, 375-400. [CrossRef]

76. Kautonen, T.; Van Gelderen, M.; Tornikoski, E.T. Predicting entrepreneurial behaviour: A test of the theory of planned behavior. Appl. Econ. 2013, 45, 697-707. [CrossRef]

77. Kautonen, T.; Van Gelderen, M.; Fink, M. Robustness of the theory of planned behavior in predicting entrepreneurial intentions and actions. Enterp. Theory Pract. 2015, 39, 655-674. [CrossRef]

78. Bandura, A. Social cognitive theory in cultural context. Appl. Psychol. Int. Rev. 2002, 51, 269-290. [CrossRef] 
79. Brockhaus, R.H. Risk taking propensity of entrepreneurs. Acad. Manag. J. 1980, 23, 509-520.

80. Norman, P.; Hoyle, S. The theory of planned behavior and breast self-examination: Dinstinguishing between perceived control and self-efficacy. J. Appl. Soc. Psychol. 2004, 34, 694-708. [CrossRef]

81. Chen, C.C.; Greene, P.G.; Crick, A. Does entrepreneurial self-efficacy distinguish entrepreneurs from managers? J. Bus. Ventur. 1998, 13, 295-316. [CrossRef]

82. Bullough, A.; Renko, M.; Myatt, T. Danger Zone Entrepreneurs: The Importance of Resilience and Self-Efficacy for Entrepreneurial Intentions. Enterp. Theory Pract. 2014, 38, 473-499. [CrossRef]

83. Asimakopoulos, G.; Hernández, V.; Miguel, J.P. Entrepreneurial Intention of Engineering Students: The Role of Social Norms and Entrepreneurial Self-Efficacy. Sustainability 2019, 11, 4314. [CrossRef]

84. Mitchell, R.K.; Busenitz, L.; Lant, T. Toward a theory of entrepreneurial cognition: Rethinking the people side of entrepreneurship research. Enterp. Theory Pract. 2002, 27, 93-104. [CrossRef]

85. Boyd, N.G.; Vozikis, G.S. The influence of self-efficacy on the development of entrepreneurial intentions and actions. Enterp. Theory Pract. 1994, 18, 63-77. [CrossRef]

86. Robinson, P.B.; Stimpson, D.V.; Huefner, J.C.; Hunt, H.K. An attitude approach in the prediction of entrepreneurship. Enterp. Theory Pract. 1991, 15, 13-31. [CrossRef]

87. Vinothkumar, M.; Subramanian, S. Self-Efficacy, Attitude and Subjective Norms as Predictors of Youth's Intention to Enlist in Defence Service. J. Indian Acad. Appl. Psychol. 2016, 42, 309-318.

88. Zhao, H.; Seibert, S.E.; Hills, G.E. The mediating role of self-efficacy in the development of entrepreneurial intentions. J. Appl. Psychol. 2005, 90, 1265-1272. [CrossRef]

89. Lee, S.H.; Wong, P.K. An exploratory study of technopreneurial intentions: A career anchor perspective. J. Bus. Ventur. 2004, 19, 7-28. [CrossRef]

90. Thompson, E.R. Individual entrepreneurial intent: Construct clarification and development of an internationally reliable metric. Enterp. Theory Pract. 2009, 33, 669-694. [CrossRef]

91. Liñán, F; Chen, Y.W. Development and Cross-Cultural Application of a Specific Instrument to Measure Entrepreneurial Intentions. Enterp. Theory Pract. 2009, 33, 593-617. [CrossRef]

92. Zapkau, F.B.; Schwens, C.; Steinmetz, H.; Kabst, R. Disentangling the effect of prior entrepreneurial exposure on entrepreneurial intention. J. Bus. Res. 2015, 68, 639-653. [CrossRef]

93. Boudreau, M.C.; Gefen, D.; Straub, D.W. Validation in Information Systems Research: A State-of-the-Art Assessment. MIS Q. 2001, 25, 1-26. [CrossRef]

94. Liñán, F. Skill and value perceptions: How do they affect entrepreneurial intentions? Int. Entrep. Manag. J. 2008, 4, 257-272. [CrossRef]

95. Kline, R.B. Principles and Practice of Structural Equation Modeling; Guilford Press: New York, NY, USA, 2004.

96. MacCallum, R.C.; Browne, M.W. The use of causal indicators in covariance structure models: Some practical issues. Psychol. Bull. 1993, 114, 533-541. [CrossRef] [PubMed]

97. Franke, G.R.; Preacher, K.J.; Rigdon, E.E. Proportional structural effects of formative indicators. J. Bus. Res. 2008, 61, 1229-1237. [CrossRef]

98. Hair, J.F.; Ringle, C.M.; Sarstedt, M. PLS-SEM: Indeed a Silver Bullet. J. Mark. Theory Pract. 2011, 19, 139-152. [CrossRef]

99. Chin, W.W.; Marcolin, B.L.; Newsted, P.R. A Partial Least Squares Latent Variable Modeling Approach for Measuring Interaction Effects: Results from a Monte Carlo Simulation Study and an Electronic-Mail Emotion/Adoption Study. Inf. Syst. Res. 2003, 14, 189-217. [CrossRef]

100. Chan, Y.H. Biostatistics 101: Data presentation. Singap. Med. J. 2003, 44, 280-285.

101. Hair, J.F.; Risher, J.J.; Sarstedt, M.; Ringle, C.M. When to use and how to report the results of PLS-SEM. Eur. Bus. Rev. 2019, 31, 2-14. [CrossRef]

102. Chin, W.W. The Partial Least Squares Approach to Structural Equation Modeling. Adv. Hosp. Leis. 1998, 8, $295-336$.

103. Hulland, J. The use of partial least square (PLS) in strategic management research: A review of four recent studies. Strateg. Manag. J. 1999, 20, 195-204. [CrossRef]

104. Nunnally, J.C.; Bernstein, I.H. Psychometric Theory; McGraw-Hill: New York, NY, USA, 1994.

105. Hair, J.F.; Anderson, R.E.; Tatham, R.L.; Black, W.C. Multivariate Data Analysis, 5th ed.; Prentice Hall: Englewood Cliffs, NJ, USA, 1999.

106. Fornell, C.; Larcker, D.F. Evaluating structural equation models with unobservable variables and measurement error. J. Mark. Res. 1981, 18, 39-50. [CrossRef]

107. Hair, J.F.; Black, W.C.; Babin, B.J.; Anderson, R.E.; Tatham, R.E. Multivariate Data Analysis, 6th ed.; Pearson Prentice Hall: Upper Saddle River, NJ, USA, 2006.

108. Sun, Y.; Wang, N.; Yin, C.; Zhang, J.X. Understanding the relationships between motivators and effort in crowdsourcing marketplaces: A nonlinear analysis. Int. J. Inf. Manag. 2015, 35, 267-276. [CrossRef]

109. Peng, D.X.; Lai, F. Using partial least squares in operations management research: A practical guideline and summary of past research. J. Oper. Manag. 2012, 30, 467-480. [CrossRef]

110. Götz, O.; Liehr-Gobbers, K.; Krafft, M. Evaluation of structural equation models using the partial least squares (PLS) approach. In Handbook of Partial Least Squares: Concepts, Methods and Applications; Vinci, V.E., Chin, W.W., Henseler, J., Wang, H., Eds.; Springer: Berlin/Heidelberg, Germany, 2010; pp. 691-711. 
111. Diamantopoulos, A.; Winklhofer, H.M. Index construction with formative indicator. J. Mark. Res. 2001, 38, 269-277. [CrossRef]

112. Diamantopoulos, A.; Siguaw, J.A. Formative Versus Reflective Indicators in Organizational Measure Development: A Comparison and Empirical Illustration. Br. J. Manag. 2006, 17, 263-282. [CrossRef]

113. Cenfetelli, B.R.T.; Bassellier, G. Interpretation of Formative Measurement in Information Systems Research. MIS Q. 2009, 33, 689-708. [CrossRef]

114. Brettel, M.; Engelen, A.; Müller, T.; Schilke, O. Distribution Channel Choice of New Entrepreneurial Ventures. Enterp. Theory Pract. 2011, 35, 683-708. [CrossRef]

115. Klein, R.; Rai, A. Interfirm strategic information flows in logistics supply chain relationships. MIS Q. 2009, 33, 735-762. [CrossRef]

116. Tenenhaus, M.; Vinzi, V.E.; Chatelin, Y.M.; Lauro, C. PLS path modeling. Comput. Stat. Data Anal. 2005, 48, 159-205. [CrossRef]

117. Wetzels, M.; Odekerken-Schroeder, G.; Oppen, C.V. Using PLS path modeling for assessing hierarchical construct models: Guidelines and empirical illustration. MIS Q. 2009, 33, 177-195. [CrossRef]

118. Henseler, J.; Ringle, C.M.; Sinkovics, R.R. The use of partial least squares path modeling in international marketing. In New Challenges to International Marketing; Advances in International Marketing; Emerald Group Publishing Limited: Bingley, UK, 2009; Volume 20, pp. 277-319.

119. Shrout, P.E.; Bolger, N. Mediation in Experimental and Nonexperimental Studies: New Procedures and Recommendations. Psychol. Methods 2002, 7, 422-455. [CrossRef] [PubMed]

120. Ahuja, M.K.; Galletta, D.F.; Carley, K.M. Individual Centrality and Performance in Virtual R\&D Groups: An Empirical Study. Manag. Sci. 2003, 49, 21-38.

121. Huang, Y.J.; Lv, Y.J. The Problems and Countermeasures of Entrepreneurship Education in Chinese Colleges and Universities. Educ. Res. 2018, 39, 81-87.

122. Liu, Y.Y.; Bian, S. Problems' Causes and Countermeasure Analysis of Innovation and Entrepreneurship Education in Colleges and Universities. Mod. Educ. Manag. 2019, 9, 32-37.

123. Yurtkorua, S.E.; Kuşcub, Z.K.; Doğanayc, A. Exploring the antecedents of entrepreneurial intention on Turkish university students. Proc. Soc. Behav. Sci. 2014, 150, 841-850. [CrossRef]

124. Sesen, H. Personality or environment? A comprehensive study on the entrepreneurial intentions of university students. Educ. Train. 2013, 55, 624-640. [CrossRef]

125. De Moraes, G.H.S.M.; Sadao, I.E.; Matheus, P. Effects of Entrepreneurial Characteristics and University Environment on Entrepreneurial Intention. Rev. Adm. Contemp. 2018, 22, 226-248. [CrossRef]

126. Nowiński, W.; Haddoud, M.; Wach, K.; Schaefer, R. Perceived public support and entrepreneurship attitudes: A little reciprocity can go a long way! J. Vocat. Behav. 2020, 121, 103474. [CrossRef]

127. Cavazos-Arroyo, J.; Puente-Díaz, R.; Agarwal, N. An examination of certain antecedents of social entrepreneurial intentions among Mexico residents. Rev. Bras. Gest. Negóci. 2017, 19, 180-199.

128. Utami, C.W. Attitude, Subjective Norms, Perceived Behaviour, Entrepreneurship Education and Self-efficacy toward Entrepreneurial Intention University Student in Indonesia. Eur. Res. Stud. J. 2017, 20, 475-495.

129. Rosique-Blasco, M.; Madrid-Guijarro, A.; García-Pérez-de-Lema, D. The effects of personal abilities and self-efficacy on entrepreneurial intentions. Int. Entrep. Manag. J. 2018, 14, 1025-1052. [CrossRef]

130. Yap, S.F.; Orthman, M.N.; Wee, Y.G. Comparing theories to explain exercise behaviour: A socio-cognitive approach. Int. J. Health Promot. Educ. 2013, 51, 134-143. [CrossRef]

131. Fenech, R.; Baguant, P.; Ivanov, D. Entrepreneurial Attitudes, Self-Efficacy, and Subjective Norms Amongst Female Emirati Entrepreneurs. Int. J. Entrep. 2019, 23, 1-11.

132. Izquierdo, E.; Buelens, M. Competing Models of Entrepreneurial Intentions: The Influence of Entrepreneurial Self-efficacy and Attitudes. Int. J. Entrep. Small Bus. 2011, 13, 75-91. [CrossRef]

133. Bagozzi, R.P.; Kimmel, S.K. A comparison of leading theories for the prediction of goal-directed behaviours. Br. J. Soc. Psychol. 1995, 34, 437-461. [CrossRef]

134. Fayolle, A.; Liñán, F. The future of research on entrepreneurial intentions. J. Bus. Res. 2014, 67, 663-666. [CrossRef]

135. Klyver, K.; Schøtt, T. How Social Network Structure Shapes Entrepreneurial Intentions? J. Glob. Entrep. Res. 2011, 1, 3-19. 